\title{
Assessment of biogas production from MBT waste under different operating conditions
}

Pantini, Sara; Verginelli, Jason; Lombardi, Francesco; Scheutz, Charlotte; Kjeldsen, Peter

Published in:

Waste Management

Link to article, DOI:

10.1016/j.wasman.2015.06.019

Publication date:

2015

Document Version

Peer reviewed version

Link back to DTU Orbit

Citation (APA):

Pantini, S., Verginelli, J., Lombardi, F., Scheutz, C., \& Kjeldsen, P. (2015). Assessment of biogas production from MBT waste under different operating conditions. Waste Management, 43, 37-49.

https://doi.org/10.1016/j.wasman.2015.06.019

\section{General rights}

Copyright and moral rights for the publications made accessible in the public portal are retained by the authors and/or other copyright owners and it is a condition of accessing publications that users recognise and abide by the legal requirements associated with these rights.

- Users may download and print one copy of any publication from the public portal for the purpose of private study or research.

- You may not further distribute the material or use it for any profit-making activity or commercial gain

- You may freely distribute the URL identifying the publication in the public portal 


\section{Assessment of biogas production from MBT waste under different operating}

2

4

5

\section{Abstract}

\section{conditions}

Sara Pantini ${ }^{1}{ }^{*}$, Iason Verginelli ${ }^{1}$, Francesco Lombardi ${ }^{1}$, Charlotte Scheutz ${ }^{2}$, Peter Kjeldsen ${ }^{2}$

${ }^{1}$ Department of Civil Engineering and Computer Science Engineering, University of Rome "Tor Vergata"

Via del Politecnico, 1, 00133 Rome (Italy)

Tel.: +3906 72597497; fax: +390672597021

*E-mail address: pantini@ing.uniroma2.it

${ }^{2}$ Department of Environmental Engineering, Technical University of Denmark Miljoevej, Building 113, DK-2800 Kgs. Lyngby (Denmark)

In this work, the influence of different operating conditions on the biogas production from mechanicallybiologically treated (MBT) wastes is investigated. Specifically, different lab-scale anaerobic tests varying the water content (26-43\%w/w up to $75 \% \mathrm{w} / \mathrm{w}$ ), the temperature (from $20-25^{\circ} \mathrm{C}$ up to $55^{\circ} \mathrm{C}$ ) and the amount of inoculum have been performed on waste samples collected from a full-scale Italian MBT plant. For each test, the gas generation yield and, where applicable, the first-order gas generation rates were determined. Nearly all tests were characterised by a quite long lag-phase. This result was mainly ascribed to the inhibition effects resulting from the high concentrations of volatile fatty acids (VFAs) and ammonia detected in the different stages of the experiments. Furthermore, water content was found as one of the key limiting factor of the anaerobic biological process. Indeed, the experimental results showed that when 
the moisture was lower than $32 \% \mathrm{w} / \mathrm{w}$, the methanogenic microbial activity was completely inhibited. For the higher water content tested ( $75 \% \mathrm{w} / \mathrm{w}$ ), high values of accumulated gas volume (up to $150 \mathrm{NI} / \mathrm{kgTS}$ ) and a relatively short time period to deplete the MBT waste gas generation capacity were observed. At these test conditions, the effects of temperature became evident, leading to gas generation rates of $0.007 d^{-1}$ at room temperature that increased to $0.03-0.05 \mathrm{~d}^{-1}$ at $37{ }^{\circ} \mathrm{C}$ and to $0.04-0.11 \mathrm{~d}^{-1}$ at $55{ }^{\circ} \mathrm{C}$. Overall, the obtained results highlighted that the operative conditions can drastically affect the gas production from MBT wastes. This suggests that particular caution should be paid when using the results of lab-scale tests for the evaluation of long-term behaviour expected in the field where the boundary conditions change continuously and vary significantly depending on the climate, the landfill operative management strategies in place (e.g. leachate recirculation, waste disposal methods), the hydraulic characteristics of disposed waste, the presence and type of temporary and final cover systems.

\section{KEYWORDS}

mechanically biologically treated waste; biochemical methane potential test (BMP); anaerobic tests; gas generation model; first-order kinetic constants

\section{Introduction}

Landfills still represent the dominant option for waste disposal in many parts of the world (Laner et al. 2012). However, as known, this option may pose a threat to groundwater pollution, soil contamination and global warming effects due to the potential emission of leachate and landfill gas to the surrounding environment (Pantini et al., 2014; Scaglia et al., 2010; Thomsen et al., 2012; White and Beaven, 2013). Indeed, landfill has been recognized as one of the main source of anthropogenic methane emission and a significant contributor to global warming (Bogner et al., 2008). Gas emissions from landfills are mainly dominated by methane and carbon dioxide that are generated from the anaerobic conversion of organic matter contained in waste as a result of biological processes naturally occurring in landfill sites. Moreover, due to the generally high nitrogen content in wastes, there is also a considerable potential for nitrous oxide 
emissions from municipal solid waste (MSW) landfills that can further enhance the global warming effects (Harborth et al., 2013).

In view of these concerns, throughout the world, new regulations in waste management and treatment strategies of municipal solid waste (MSW) have been introduced. For instance, in Europe, the Landfill European Directive 1999/31/EC imposes member states only landfill wastes that have been preliminary subjected to treatment or incineration. The directive aims at limiting the amount of biodegradable waste in landfills while encouraging alternative strategies in order to move towards more sustainable waste management system, according to the waste hierarchy approach (De Gioannis et al., 2009; Sormunen et al., 2008). To meet the European targets, member states have adopted different options, such as separate collection and recycling of organic waste stream, MSW incineration with energy recovery, biological treatments of source separated organic wastes or Mechanical Biological Treatment (MBT) plants of residual MSW (Lornage et al., 2007; Pantini et al., 2015; Scaglia et al., 2010). Among these, the MBT technology is playing a key role in the waste management system of unsorted MSW wastes (Adani et al., 2004; Farrell and Jones, 2009; Pantini et al., 2015; Siddiqui et al., 2013;). All over Europe, MBT facilities can apply different combinations of mechanical sorting, bio-drying, and biological processes depending on the specific target, that may be a pre-treatment before incineration or a pre-treatment to produce a biostabilized product that has a lower impact when disposed of in landfills (Adani et al., 2004; Di Maria et al., 2013; Farrell and Jones, 2009; Montejo et al., 2013). In the latter case, the MBT plant consists of a mechanical pre-processing stage including crushing, sieving and recovering of recyclable materials (such as metals, glass and plastics). This stage leads to two distinct flows: the oversize fraction, which is further processed to produce refuse-derived fuel, and the undersize fraction, rich in organic putrescible matter, which is biologically treated using an anaerobic/aerobic process in order to stabilize it. The main distinction between different MBT systems concerns the sequence of process steps and the type and duration of the biological treatment (Pan and Voulvoulis, 2007; Pantini et al., 2015). The specific technology and process applied may strongly affect the long-term behaviour of MBT wastes in landfills in terms of both liquid composition and gas generation (Boldrin et al., 2011; Siddiqui et al., 2013). However, gas emissions from MBT waste have been rarely measured on full scale MBT landfills (Harborth et al., 2013). Hence, the current 
state of knowledge on biogas emissions is based either on laboratory tests or on large scale experiments such as lysimeters (Sormunen et al., 2008). Depending on the specific aim of the test, lab scale studies on gas emissions from MBT wastes and solid organic wastes are usually carried out using different procedures and operative conditions (see Table 1). As highlighted by Lornage et al. (2007), the differences in the experimental procedure adopted may modify the biogas yield and kinetics, thus leading to results that are not always comparable. The anaerobic process is indeed sensitive to several factors such as $\mathrm{pH}$, water content, temperature, particle size, as well as by the presence of inhibitors such as of volatile fatty acids (VFAs), ammonia and heavy metals (Cabbai et al., 2013; Elbeshbishy et al., 2012; Labatut et al., 2011; Lornage et al., 2007; Raposo et al., 2011). Among these, pH is recognised as the key parameter to be maintained in an appropriate range (6.4-7.5) in order to enhance the methane yield (Adani et al., 2004; Argun et al., 2008; Lo et al., 2010). High pH values would result in increased toxicity due to the shift to higher concentrations of ammonia, which is identified as one of the most toxic agent for methanogenic bacteria (Chen et al., 2008; Vigneron et al., 2007). In contrast, low pH values are indicative of the accumulation of VFAs within the system (Bouallagui et al., 2005; Li et al., 2011). VFAs represent the main intermediate products during the initial acidogenic stage of the anaerobic process that are successively converted into methane and carbon dioxide. However, VFAs concentrations at high level may result in an inhibition of the methanogenic activity, as observed by several authors (Argun et al., 2008; Borzacconi et al., 1997; Cabbai et al., 2013). Regarding the other operative conditions, an increase of temperature has a positive effect on the microbial growth and activity (Chen et al., 2008) thus leading to a faster gas generation process. Similarly, increasing the water content of incubated waste is beneficial for methane yield since it enhances the solute transport of nutrient, the organic matter solubilisation and the microorganism mobilization within micro-environments, as well as dilutes the concentration of inhibitors (Donovan et al., 2010; Mora-Naranjo et al., 2004). Finally, the particle size of materials exerts a relevant influence on the process kinetic; it is well accepted that particle size reduction results in higher methane generation rate (Esposito et al., 2012; Lesteur et al., 2010, Mata-Alvarez et al., 2000), whereas its effect on biogas yield is still not completely elucidated (Mshandete et al., 2006; Nopharatana et al., 2007). 
The objective of this work was to evaluate the effects of temperature, water content and inoculum addition on biogas generation from mechanically-biologically treated waste by performing anaerobic batch tests at different operating conditions. Furthermore, in order to determine the potential gas generation capacity under optimal conditions, biomethane potential tests (BMP) were carried out. All these tests were then compared in terms of cumulative biogas yield and rates. Besides, where applicable, a first-order kinetic model was used to compute the biogas rate constants from the cumulative gas generation curves observed in each experiment. Finally, the obtained results were addressed to assess the possible implications resulting from the different environmental conditions expected in the field.

\section{Materials and Methods}

\subsection{MBT waste material}

Mechanically-biologically treated waste samples were collected at the belt discharge point of the secondary refinement unit of a full-scale MBT plant operating in Italy. This MBT plant receives residual municipal solid waste $(226,000$ ton/y in 2013), with the average composition shown in Table 2.

\section{Table 2}

In this plant the incoming wastes are subjected to a mechanical pre-processing consisting of pre-sorting of bulky materials, shredding and size separation. From these processes two flows are obtained: the light fraction with particle size $>80 \mathrm{~mm}(96,500$ ton/y in 2013), which is further processed to produce refuse derived fuel $(55,500$ ton/y in 2013), and the undersize fraction $(126,000$ ton/y in 2013), which is sent to the biostabilization basins; the remaining flow is represented by recovered metals (3500 ton/y in 2013). In the biostabilization basins, the aerobic process occurs for 28 days at forced ventilation condition, with daily water addition and waste turning. Then, the stabilized output goes to a secondary sieving process to remove improper materials. The undersize fraction $(<20 \mathrm{~mm})$ is the organic MBT waste analysed in this study. The MBT waste sample was collected in May 2014 using standard procedures (UNI 10802:2013). A final MBT waste sample of about $80 \mathrm{~kg}$ was sent to the laboratory and stored at $4{ }^{\circ} \mathrm{C}$ for few days until the physico-chemical analyses were performed. In the laboratory, three representative sub-samples were 
obtained by the "coning and quartering" method. One sub-sample was analysed to determine the moisture content (W), total (TS) and volatile solids (VS), pH, total (TC) and organic carbon (TOC) content, total Kjeldahl (TKN) and soluble nitrogen $\left(\mathrm{NH}_{4}-\mathrm{N}\right)$, the Chemical Oxygen Demand (COD) and the water content at field capacity $(F C)$ of waste (i.e. the water-retaining capacity including both the hygroscopic and capillary water). All measurements were performed at least in triplicate; initial waste water content, dry matter and waste field capacity are expressed as percentage of wet weight whereas the other parameters are computed on dry weight basis. Average values and standard deviations are reported in Table 2. A subsample (3-4 kg) was used for BMP tests. Before to perform the BMP analysis, the sub-sample was dried at room temperature $\left(25^{\circ} \mathrm{C}\right)$ to avoid losses of volatile organic compounds and then shredded to $1 \mathrm{~mm}$ particle size. The last sub-sample was used in the incubation tests as received since, currently, the MBT waste is not subjected to further treatment before landfilling it.

\subsection{Analytical Methods}

In order to characterize the MBT waste with regards to its physical and chemical properties, different analytical methods were applied. These tests provide basic information that are essential for the interpretation of the biological test results.

\section{Moisture content (W), total (TS) and volatile solids (VS), total carbon (TC) and organic carbon (TOC)} content, $\mathrm{pH}$

Moisture (W) and total solid (TS) content were determined according to the standard method UNI EN 14346 (2006). Volatile solids (VS) were measured by loss-on-ignition (LOI) at $550^{\circ} \mathrm{C}$ for $8 \mathrm{~h}$ (UNI/TS 11184 , 2006). Total carbon (TC) and organic carbon content (TOC) were analysed by Shimadzu SSM-5000A instrument according to UNI EN 13137( 2001). The own pH of MBT waste was determined after elution following the standard method UNI EN 12457-2 (2004).

\section{Total (TKN) and soluble nitrogen $\left(\mathrm{NH}_{4}-\mathrm{N}\right)$}

Total Kjeldahl Nitrogen (TKN) was measured on solid waste samples (2.5-3 g) by mineralization with a strong acid medium ( $97 \%$ sulphuric acid) followed by steam distillation and titrimetric determination, as 
proposed by Mohajer et al. (2010) and Tremier et al. (2005). Blank and control tests were performed 151 simultaneously, in triplicate. In blank tests, $4 \mathrm{ml}$ of deionized water were used whereas in control tests, to 152 evaluate the efficiency of ammonia recovery, $4 \mathrm{ml}$ of L-glutamic acid (1000 mg/l) were utilized. Samples were digested in FOSS 2020 Digestor at $180^{\circ} \mathrm{C}$ for $1 \mathrm{~h}$ and thereafter at $350^{\circ} \mathrm{C}$ for $1-2$ hours (warm-up time excluded). After cooling, samples were distilled using FOSS Kjeltec 8100 distillation unit. In the distillation method, $30 \mathrm{ml}$ of deionized water and $70 \mathrm{ml}$ of the alkaline solution ( $32 \% \mathrm{w} / \mathrm{w} \mathrm{NaOH}$ ) were added to each tube. The steam supply was set to $60 \%$ and the distillation time was 5 minutes. A solution consisting of 50 $\mathrm{ml}$ deionized water, $4 \mathrm{ml}$ boric acid $(40 \mathrm{~g} / \mathrm{l})$ and 3 drops of Kjeldhal indicator (mixture of methyl red indicator and Bromocresol green indicator, MERCK KGaA) was used as absorbent solution during distillation. The ammonia content was determined by tritation of distillate with $0.1 \mathrm{M} \mathrm{H}_{2} \mathrm{SO}_{4}$.

Determination analyses of soluble nitrogen $\left(\mathrm{NH}_{4}-\mathrm{N}\right)$ were carried out on 2.5-3 g using the same procedure of TKN. For the distillation method, $30 \mathrm{ml}$ of deionized water and $50 \mathrm{ml}$ of the alkaline solution $(32 \% \mathrm{w} / \mathrm{w}$ $\mathrm{NaOH}$ ) were added to each tube. Steam supply and distillation time were the same as mentioned above, as well as the titration method. The ammonia recovery of the instrument was evaluated by adding $4 \mathrm{ml}$ of a known solution (1000 mg/l $\mathrm{NH}_{4}-\mathrm{N}$ ) to $50 \mathrm{ml}$ of deionized water. An efficiency up to $100 \%$ was detected.

\section{Chemical Oxygen Demand (COD)}

To determine the COD of wet solid samples, the modified method proposed by Raposo et al. (2008) was adopted. This method consists of a wet oxidation with potassium dichromate as the oxidant and silver sulphate as the catalyst in a strong sulphuric acid solution (Raposo et al., 2008). COD measurements were carried out on $1.0 \mathrm{~g}$ of MBT waste sample, adding $6 \mathrm{ml}$ of $97 \%$ sulphuric acid and $30 \mathrm{ml}$ of deionized water to the flask while stirring it for 30 minutes. Then, $2.0 \mathrm{ml}$ of Potassium Dichromate $0.025 \mathrm{M}$ (for high range detection) and $4.5 \mathrm{ml}$ of silver sulphate sulphuric acid solution were added to each flask containing $3.5 \mathrm{ml}$ of initial solution. The reaction mixtures were boiled in a Holm \& Halby Techne Dri Block at $148 \pm 2{ }^{\circ} \mathrm{C}$ for 110 minutes. After cooling, $5.0 \mathrm{ml}$ of deionized water and 3 drops of ferroin indicator were added and samples were titrated with $0.035 \mathrm{M}$ Ferrous Ammonium Sulphate solution. COD measurements were 
performed in triplicate. Five blanks $(3.5 \mathrm{ml}$ of deionized water) and three control tests $(3.5 \mathrm{ml}$ of $500 \mathrm{mg}$ COD/I standard solution) were carried out simultaneously.

\section{Volatile Fatty Acids (VFAs)}

VFAs were measured in fresh solid waste as well as in waste samples at different incubation time. Samples were prepared weighing about $5 \mathrm{~g}$ of MBT waste, adding $12.5 \mathrm{ml}$ of deionized water and acidifying them with $0.4 \mathrm{ml}$ of $97 \%$ sulphuric acid to ensure $\mathrm{pH}<2$. A magnet was inserted and samples stirred for approximatively $10-15$ minutes to homogenize them. Then, $1.5 \mathrm{ml}$ of each sample was placed in an Eppendorf tube and centrifuged at Eppendorf mini spin table centrifuge at 13,400 rpm for $10 \mathrm{~min}$. After centrifugation, $1.0 \mathrm{ml}$ sample was transferred to a GC glass vial and $0.1 \mathrm{ml}$ of internal standard (2.2 $\mathrm{mM} 4$ Methyl valeric acid) was added. Concentrations of acetate, propionate, iso-butyrate, butyrate, iso-valerate, valerate, hexanoic acids were determined by using GC Shimadzu GC - 2010 equipped with and FID (flameionization-detector). VFA compounds were separated by a capillary column (ZB - FFAP, $30 \mathrm{~m}, 0,53 \mathrm{~mm}$ I.D $\mathrm{x}$ $1,0 \mu \mathrm{m})$ and concentrations were computed by means of a linear calibration curve obtained after standards injection (range: 5-1500 mg/l). All measurements were performed in triplicate.

\section{MBT waste field capacity (FC)}

Water content of MBT waste at field capacity was determined by performing column test. A Plexiglas column with an inner diameter of $3.5 \mathrm{~cm}$ and a total height of $15 \mathrm{~cm}$ was packed with about $70 \mathrm{~g}$ of as received MBT waste (water content at $19.4 \% \mathrm{w} / \mathrm{w}$ ), corresponding to initial wet density of $0.5 \mathrm{~g} / \mathrm{cm}^{3}$ (dry bulk density of $\left.0.4 \mathrm{~g} / \mathrm{cm}^{3}\right)$. The packed column was weighted $\left(M_{\text {in }}\right)$ and then saturated from the bottom section until a water head of few millimeters formed at the top and the pump was stopped. After saturation, the column was let drain until no significant outgoing flow was detected and weighted again $\left(M_{\text {end }}\right)$. The difference in weight $\left(M_{\text {end }}-M_{\text {in }}\right)$ is the adsorbed water $\left(M_{w, a d s}\right)$. The ratio between the total water in the column at the end of the experiment (i.e. sum of adsorbed water and initial moisture water, W) and the final mass of MBT material in the column $\left(M_{i n, M B T}+M_{w, a d s}\right)$, shown in Eq. (1), represents a rough estimation of the field capacity of MBT waste (expressed as percentage of wet weight): 


\subsection{Gas production tests}

\section{Biochemical Methane Potential test (BMP)}

Different BMP assays, experimental set-ups and employed protocols can be found in literature due to a lack of harmonization and standardization of biochemical methane potential methods. Indeed, some methods are designed to evaluate the biodegradability of chemical substances under methanogenic conditions (ISO 14853, 1999; ASTM E2170-01, 2008 (withdrawn 2013); ASTM D5210-92, 2007; DIN 38414-8, 1985) while others aim at quantifying the ultimate biodegradability and gas generation of complex organic substrates (ISO 11734, 1995; ISO/DIS 14853, 1999) using different experimental set-ups. Additionally, these methods were applied differently or modified by researchers (Angelidaki et al., 2009), making the inter-comparison of BMP test results quite difficult. In this study, the BMP protocol proposed by Hansen et al. (2004) was adopted. Glass bottles ( $1 \mathrm{l})$ with a thick rubber septum were used as reactors. Approximatively $1 \mathrm{~g}$ of air dried waste sample (particle size $<1 \mathrm{~mm}$ ), $80 \mathrm{ml}$ of deionized water and $320 \mathrm{ml}$ of a fresh de-gased inoculum were used in the experiments in order to achieve an organic load of $1.4 \mathrm{gVS} / \mathrm{l}$ (weight of VS in substrate per unit volume of inoculum). Tests were carried out for 30 days with six replicates, due to the relatively high heterogeneity of the MBT material. Thermophilically digested material from a full-scale biogas plant was used as inoculum. Three blanks with only water and inoculum were run to test the biogas production from the inoculum itself. Control tests, containing $0.8 \mathrm{~g}$ of AVICEL (Fluka, Sigma Aldrich, Vallensbæk Strand, Denmark) as a standard substrate, were performed to check the quality of the inoculum. After set-up, the reactors were flushed with $\mathrm{N}_{2}$ for 10 minutes, to ensure the establishment of anaerobic conditions in the headspace of the glass bottles, then sealed and placed in the incubator at $55{ }^{\circ} \mathrm{C}$ $\left( \pm 1{ }^{\circ} \mathrm{C}\right)$. The methane concentration in the reactors was measured every two days during the first two weeks, and later once per week. Gas samples $(0.2-0.5 \mathrm{ml})$ were taken from the headspace of the reactors by using a syringe with a pressure lock and directly injected into the gas chromatograph for methane determination (Shimadzu GC 14A) and for qualitative analysis of gas composition in terms of $\% \mathrm{CH}_{4}$ and 
$\% \mathrm{CO}_{2}$ (Mikrolab GC Aarhus ). In order to avoid build-up of high pressure inside the reactors, the gas was

released during the experiment. Based on the difference of $\mathrm{CH}_{4}$ concentration before and after release of excess gas, the generated amount of $\mathrm{CH}_{4}$ was computed.

\section{8}

\section{Anaerobic gas generation tests}

In order to evaluate the effects of temperature and water content on the gas generation rate and yield, anaerobic batch tests were performed at three different temperatures: room temperature $\left(20-25^{\circ} \mathrm{C}\right), 37^{\circ} \mathrm{C}$ and $55^{\circ} \mathrm{C}$. In tests at room temperature and $37{ }^{\circ} \mathrm{C}$, a mesophilic inoculum derived from a biogas plant carrying out mesophilic co-digestion of manure and organic waste was utilized whereas in tests at $55^{\circ} \mathrm{C}$ the same inoculum of BMP tests (thermophilically digested material) was used.

Before starting the anaerobic tests, different amounts of water were added to four MBT sub-samples (as received material with $19.4 \%$ water content) in order to achieve four values of the initial water content in waste: $26 \%, 32 \%, 38 \%, 43 \%$ (expressed on wet weight basis). After homogenizing the samples, an aliquot of each sub-sample at the specific water content was weighted and introduced into reactor and then incubated at the corresponding temperature. The values set for temperature and water content aimed at covering the actual ranges generally observed at real scale landfill sites (Mor et al., 2006; Mora-Naranjo et al., 2004). Note that the operating conditions of anaerobic tests were selected in order to simulate different disposal scenarios and, hence, they differ from the optimal ranges usually set in biogas plant treating MSW waste organic fractions. Namely, in these plants, the anaerobic digestion of incoming feedstock, usually mixed with a large amount of digester effluent or sewage sludge, may be carried out in dry systems (60-80\% water content) or in wet systems (water content $>90 \%$ ) at thermophilic or mesophilic conditions in continuous or static digesters (Braber 1995; Gunaseelan 1997; Schievano et al., 2010).

Incubation tests at $37{ }^{\circ} \mathrm{C}$ and $55^{\circ} \mathrm{C}$ consisted of 1 I glass bottle filled with waste sample (0.5-0.7 kg), sealed with a rubber septum and equipped with a PVC pipe, which connected it to a 3 I SKC Tedlar Sampling Bag (SKC Inc., Eighty Four, PA, US) for gas collection. At each measurement, $5 \mathrm{ml}$ of gas were sampled with a syringe and injected into evacuated glass vials fitted with pierceable rubber septa (Exetainer Vail, Labco Ltd, Lampeter, UK), which were then analysed for determining gas composition. A 490-PRO Micro GC (Agilent 
Technologies Denmark Aps, Glostrup, Denmark) equipped with two columns (PoraPLOT Q PLOT, 0.25mm, $10 \mathrm{~m}$, and Molecular Sieve 5A PLOT, $0.25 \mathrm{~mm}, 20 \mathrm{~m}$ ) was used to measure $\mathrm{CH}_{4}, \mathrm{CO}_{2}$ and $\mathrm{O}_{2}$ in gas samples with a detection limit of $0.1 \%$ for all gases. In the incubation tests at room temperature, 12 I steel drums with airtight lids were used as reactors. Drums were filled with MBT waste samples at three different water contents $(26 \%, 34 \%, 43 \%)$ and flushed with nitrogen for 30 minutes before sealing them. Lids were equipped with T-shaped sampling ports and connected to 5 I SKC Tedlar Sampling Bags. More information about tests conditions and experimental activities are reported in Table 3.

As shown in this table, the anaerobic gas generation tests were carried out in three sequential stages. In the first stage, no inoculum was used. During the second stage of experimental activity, a low amount of mesophilic or thermophilic inoculum ( $20 \mathrm{~g}$ of inoculum, i.e. approximately $5 \% \mathrm{w} / \mathrm{w}$ of the waste dry matter used in the test) was introduced into the incubation bottles with lower water contents ( $T 1, T 2, T 5, T 6)$ to enhance the microbial activity. In the following stage III, due to the unexpected very low biogas production, some reactors were opened ( $R 2, T 2 A, T 3 A / B, T 4 B, T 6 A, T 7 A / B)$ in order to partially remove the material, which was then analysed with regard to $\mathrm{pH}, \mathrm{VFA}, \mathrm{TKN}$ and ammonia content. In this stage, inoculum (30 $\% \mathrm{w} / \mathrm{w}$ of waste dry matter in reactor) and water ( $230 \% \mathrm{w} / \mathrm{w}$ of waste dry matter, to obtain a final moisture content of $75 \% \mathrm{w} / \mathrm{w}$ ) were introduced within these reactors that were successively purged with nitrogen and incubated again. A triplicate measurement of the biogas production from the added inoculum was performed on blank experiments and deduced from the biogas yield of waste samples.

\section{Table 3}

The gas volume produced by each reactor was computed timing the emptying of gas bags using a Fluid Metering Inc. laboratory pump (QG, Fluid Metering Inc., Syosset, NY, US). The flow rate of the pump was tested several times during the experiment and an average flow of $0.5 \mathrm{l} / \mathrm{min}$ was measured.

\subsection{First-order gas generation model}

To compute the biogas kinetic constants under different operating conditions, the widely adopted firstorder kinetic model (Gunaseelan 1997; De Gioannis et al., 2009; Lo et al., 2010; Mou et al., 2015) was used 
276 for the interpolation of experimental data. The generic formulation, which accounts for the lag-time 277 observed in the test, is the following:

$278 L(t)=L_{0}\left[1-\exp \left(-k \cdot\left(t-t_{\text {lag }}\right)\right)\right\rfloor$

279 where $L$ is the biogas accumulation ( $\mathrm{NI} / \mathrm{kgTS}$ ) at the time $t(\mathrm{~d}), L_{0}$ the potential biogas production (NI/kgTS) 280 for the tested conditions (at optimal conditions, $L_{0}$ approaches the potential gas generation capacity 281 measured in the BMP experiments), $t$ the time over the digestion period, $t_{\text {lag }}$ the lag-phase (d) and $k$ the 282 first-order kinetic constant $\left(\mathrm{d}^{-1}\right)$.

\section{$283 \quad 3 \quad$ Results and discussions}

\subsection{MBT waste characterization}

Results of the characterization analysis performed on the MBT waste are reported in Table 4. Moisture to the range usually observed for untreated waste or poorly treated waste (Modin 2007; Pognani et al., 2010).

\section{Table 4}

\subsection{Biochemical Methane Potentials}

Figure 1 shows the cumulative $\mathrm{CH}_{4}$ generation curve measured in control (red dots) and in MBT waste tests (green dots) as a function of the incubation time. The results reported in this figure, expressed as cumulative volume of methane per gTS at standard temperature and pressure (STP) conditions $\left(0{ }^{\circ} \mathrm{C}, 1\right.$ atm), represent the average values measured in the different replicates obtained after subtracting the $\mathrm{CH}_{4}$ 
methane potential for the cellulose substrate (control) and the MBT waste, respectively. The latter was estimated from the total organic carbon (TOC) of the substrate (Table 4), as shown in Eq. (3). Assuming that the biogas generated by a complete degradation of organic carbon contains $60 \%$ of methane (that corresponds to the average $\mathrm{CH}_{4}$ concentration measured during the BMP test), a theoretical value of 268 $\mathrm{NmICH}_{4} / \mathrm{gTS}$ was computed (i.e. $60 \%$ of $\mathrm{CH}_{4}$ in biogas implies that $1 \mathrm{~g}$ of TOC generates $1.12 \mathrm{NI}$ of $\mathrm{CH}_{4}$ at STP).

$$
L_{\text {theoretical }, T O C}\left(\frac{\mathrm{NmlCH}_{4}}{g_{T S}}\right)=60 \% \mathrm{CH}_{4} \cdot \frac{1}{12 \frac{g_{C}}{\mathrm{~mol}_{C}}} \cdot 22.414\left(\frac{\mathrm{Nl}}{\mathrm{mol}}\right) \cdot 0.239 \frac{g_{\text {TOC }}}{g_{T S}} \cdot 1000
$$

From Figure 1, it can be noticed that the cumulative $\mathrm{CH}_{4}$ curves observed for control and waste samples showed a rapid increase in the first two weeks and then achieved an asymptotic value. The lag phase was absent, confirming that the BMP test was run under optimal conditions. The average cumulative methane generation in controls resulted in an average gas generation of $367 \mathrm{NmICH}_{4} / \mathrm{gTS}$ on the $13^{\text {th }}$ day after starting the batch tests and reached the theoretical potential value of $415 \mathrm{NmlCH}_{4} / \mathrm{gTS}$ in 27 days. Within the first two weeks, the methane generation curve observed in control tests appeared linear $\left(R^{2}=0.99\right)$, with an average slope of $27.5 \mathrm{NmICH}_{4} /(\mathrm{gTS} d)$. Similarly, in the first stages of the MBT waste sample test a linear methane production rate of $8.4 \mathrm{NmlCH}_{4} /(\mathrm{gTS} d)$ was observed. Thereafter, the slope rapidly decreased and the cumulative $\mathrm{CH}_{4}$ generation curve asymptotically approached a constant level of 121 $\mathrm{NmICH}_{4} / \mathrm{gTS}$. Hence, it seems that, on average, only $45 \%$ of the theoretical methane generation (i.e. 268 $\mathrm{NmICH}_{4} / \mathrm{gTS}$ ) was achieved during the BMP experiment of the MBT waste sample, most likely due to the presence of non-biodegradable fractions (plastics), recalcitrant organic substances or lower degradable compounds. Moreover, it should be noted that the theoretical methane (Eq. 3) was computed neglecting the biomass synthesis and, thus, it could be overestimated. Some authors indicate that $5-10 \%$ of organic matter is consumed by bacteria growth (Angelidaki and Sanders, 2004; Elbeshbishy et al., 2012; Labatut et al., 2011; Raposo et al., 2011) and, hence, does not contribute to $\mathrm{CH}_{4}$ production. Even though the extent of degradation achieved in a BMP test is strongly dependent on the composition of the analysed substrate as well as on the test methodology applied (substrate to inoculum ratio, test duration, inoculum 
characteristics), the $45 \%$ degradability estimated for the analysed MBT waste based on TOC content is consistent with other previous studies on similar MBT materials. For instance, using experimental results (TOC, BMP, \% $\mathrm{CH}_{4}$ in biogas) presented by Bayard et al. (2010) for different MBT wastes, the degradability of MBT waste was estimated within the range $10 \%-36 \%$ in 90 -days BMP tests. An organic carbon degradability of $42.4 \%$ was computed from results reported in Barrena et al. (2008) for aerobically treated MBT waste.

Making reference to Figure 1, some variation of accumulated $\mathrm{CH}_{4}$ volume was observed between the replicate of MBT waste tests (coefficient of variation in the range of 12.4-23.3\%), probably due to its relatively high heterogeneity and to the low amount of material tested in the BMP experiment. On the contrary, both substrate (control) and inoculum (blank) showed a good internal homogeneity with coefficients of variation in the range of $0.5-7.0 \%$ and $1.9-4.9 \%$, respectively.

From the qualitative analyses of gas composition, an average value of $60.8 \pm 1.1 \%$ and $62.4 \pm 1.4 \%$ of methane concentration in biogas was detected for sample and control, respectively. Assuming this percentage, a potential $\mathrm{CO}_{2}$ yield of $78 \pm 25 \mathrm{NmlCO}_{2} / \mathrm{gTS}$ for $\mathrm{MBT}$ waste was computed. Hence, a maximum potential gas production of $199.2 \pm 63 \mathrm{Nml} / \mathrm{gTS}$ was estimated for the analysed MBT waste. This result is consistent with some previous BMP studies performed on aerobically treated MBT wastes. For instance, Barrena et al. (2008) measured a total gas production of $187 \pm 16 \mathrm{Nl} / \mathrm{kgTS}$, with an average methane content of $57 \% \mathrm{v} / \mathrm{v}$, from MBT wastes after 32 days of aerobic treatment. Bayard et al. (2010) analysed the gas generation potential of different flows in a French MBT plant; they observed that the intermediate fraction $(<50 \mathrm{~mm})$, after 6 weeks forced-aerobic treatment, still exhibited high gas generation potential $(232 \pm 23$ $\mathrm{Nl} / \mathrm{kgTS}$ ). Lornage et al. (2007) measured a gas potential of about $160 \mathrm{NI} / \mathrm{kgTS}$ from MBT wastes subjected to 4-weeks aerobic treatment process.

\subsection{Anaerobic gas generation tests}

Figs. 2-4 show the cumulative generation curve of methane (red circles) and carbon dioxide (black squares dots) obtained for the MBT waste samples at room temperature (Fig. 2), $37^{\circ} \mathrm{C}$ (Fig. 3) and $55^{\circ} \mathrm{C}$ (Fig. 4), and 
351 for different initial water contents of waste, as a function of the incubation time. Results are expressed as

352 cumulative volume of gas per kg of total solids (TS) at STP. For comparison purposes only, the potential $\mathrm{CH}_{4}$ 353 and $\mathrm{CO}_{2}$ values computed in BMP test have also been reported in Figs. 2-4 as dotted lines. From Figs. 2-4 it 354 can be noticed that in the first stage of experimental activities that were carried out at low water contents 355 and without inoculum addition, a long lag-phase was detected for all operating conditions. During this stage, the microbial population needed to get adapted to the micro-environment and to be acclimatized to the organic substrate in order to be able to grow until a sufficient active population established and the anaerobic degradation could stably evolve. Results shown in Figs. 2-4 suggested that the duration of the lag-phase was strongly affected by both the water content of waste and the process temperature. Regarding the former parameter, it widely documented that water enhances nutrients and substrates solubilisation in the liquid phase as well as supports bacteria movement and facilitates substrate and products diffusion through the porous medium (Donovan et al., 2010; Khalid et al., 2011; Liotta et al., 2014). However, the water content of waste in a landfill disposal scenario could be quite far from the optimum value for degradation (60\% -90\%) and, thus, may become limiting for the anaerobic process due to the accumulation of inhibitors with adverse effects on bacteria population (Donovan et al., 2010). Indeed, experimental results confirmed that the water content of waste could be considered as one of the most important factors limiting methane generation and, the probability of achieving a stable methanogenic stage is significantly reduced for water contents below $32 \% \mathrm{w} / \mathrm{w}$ (wet weight) at any temperature for this type of waste.

\section{Fig. 3}

Fig. 4

Increasing the operative temperature would enhance both the substrate solubilisation and the microbial 
towards more suitable conditions for methanogenic bacteria growth, thus favouring a more rapid establishment of the methanogenic phase (Lesteur et al., 2010; Li et al., 2011; Mata-Alvarez et al., 2000). Indeed, as shown in Fig. 2 in all the experiments at room temperature methane was not detected within the first three months but only $\mathrm{CO}_{2}$ was generated at high levels $(80 \% \mathrm{v} / \mathrm{v}$, see Fig. S1 in the Supplementary information). A similar behaviour was observed by Adani et al. (2004) during 90 days incubation tests carried out on fresh and partially treated wastes (10 days of aerobic treatment). The high $\mathrm{CO}_{2}$ concentration without $\mathrm{CH}_{4}$ generation suggested that the biological process was completely inhibited at every water content in tests at room temperature, probably due to acidification effects, and revealed the poor stability degree of the analysed MBT waste. Furthermore, even though the methanogenic activity was observed in tests at higher temperature and water content, a clear instability associated with the anaerobic process was still detected.

In fact, as reported in Fig. 3, reactors at $37^{\circ} \mathrm{C}$ and water content of $38 \%$ (T3) - 43\% (T4) started producing methane after 27 days, even though $\mathrm{CH}_{4}$ concentrations were low (below 20\%). A similar trend was observed for batch tests at $55{ }^{\circ} \mathrm{C}$ (Fig. 4) where methane generation started after 22 days and 13 days for tests at moisture content of $38 \%(\mathrm{~T} 7)$ and $43 \%$ (T8), respectively. However, in all these reactors (except T8) just after few days, biogas generation slowed down. Only the experiment at higher water content and temperature (T8) managed to reach the stable methanogenic phase during the experiment (without inoculum addition), as confirmed by the $\mathrm{CH}_{4}$ concentration measured in biogas, which was in the range 45$60 \% \mathrm{v} / \mathrm{v}$ (see Fig. S3 in the Supplementary information). Even if a lag phase of 40 days was observed in these tests, the cumulative gas generation approached an asymptotic value of $29.1 \pm 2.2 \mathrm{NI} \mathrm{CH} / \mathrm{kgTS}$ and 32.6 $\pm 2.1 \mathrm{NI} \mathrm{CO}_{2} / \mathrm{kgTS}$ within 100 days (Fig. 4). These values are in line with previous studies on treated MBT waste wetted to water holding capacity in which no inoculum was added (Adani et al., 2004; De Gioannis et al., 2009). However, compared to the measured BMP value, in this test condition, a very low conversion degree was achieved (30\% of BMP value).

Overall, the results obtained during the initial experimental activity indicated that, in most of test conditions, the anaerobic process was slowed down either due to high levels of inhibiting factors or to a limited amount of active biomass inside the reactors. Hence, during stage II, a small amount of inoculum 

degradation was monitored for 20 days. After the inoculum addition, methane started to be produced in all reactors but its concentration still remained very low (below $10 \% \mathrm{v} / \mathrm{v}$ ) and then decreased again (see Tests T2B and T6B of Fig. S2 in the Supplementary information). Thus, it seems that the microorganism population inside the MBT waste was not sufficient to sustain the anaerobic degradation process. For that reason, during stage $\mathrm{III}$, in reactor $\mathrm{T} 4 \mathrm{~B}\left(\mathrm{~W}=43 \%, \mathrm{~T}=37^{\circ} \mathrm{C}\right)$ a greater amount of inoculum was introduced $(70$ g) and, in two weeks, methane concentration achieved the range typical of a stable methanogenic phase (50-70 \%v/v, see Fig. S2 in the Supplementary information).

Results shown in Figs. 3-4 also highlight the different behaviour of tests with water content at field capacity ( $w=43 \%$ at $37^{\circ} \mathrm{C}$ and $55^{\circ} \mathrm{C}$, see T4 vs. T8). In fact, even if the water content was the same in these reactors, only tests at $55{ }^{\circ} \mathrm{C}$ (see $\mathrm{T} 8$ in Fig. 4) managed to achieve the stable methanogenic phase without the inoculum addition. Instead, at $37^{\circ} \mathrm{C}$, a very low methane volume was measured in test where no inoculum was used (see T4A in Fig. 3), whereas methane was stably produced only after the addition of a significant amount $(70 \mathrm{ml})$ of mesophilic inoculum (T4B). This may be ascribed, on the one hand, to a lower active mass of mesophilic bacteria in the MBT waste compared to the thermophilic ones, presumably due to the type of biological process performed in the MBT facility. Indeed, temperatures up to $70{ }^{\circ} \mathrm{C}$ were achieved in the biostabilization basin of the MBT plant during the aerobic treatment. This sanitation process may have significantly reduced the microorganism population inside the waste mass, especially the mesophilic bacteria, which are more sensitive to high temperatures than the thermophilic ones. On the other hand, the lower gas generation measured in test T4A compared to T8 may be explained considering that the methanogenic mesophilic bacteria could be more vulnerable to unfavourable environmental conditions (higher toxic effects exerted by VFA and ammonia) and have lower growth rates (van Lier et al., 1997; Amani et al., 2011) compared to the thermophilic bacteria, that implies the adapting period could last longer. In conclusion, results obtained during stage I and II suggested that the capability of the MBT waste to generate methane is drastically limited due to inhibition effects, which are emphasized at lower water contents, also because the initial bacteria population inside the waste mass could not contain a sufficient 
load). For a better understanding of these results, during stage III of the experimental activity, reactors were opened and waste was partially removed in order to measure $\mathrm{pH}, \mathrm{VFA}$ and $\mathrm{NH}_{4}-\mathrm{N}$. Then, inoculum ( $30 \%$ of final TS) and water (up to a final moisture content of $75 \% \mathrm{w} / \mathrm{w}$ ) were added in reactors R2, T2A, T3, T6A, T7 and incubated again. The beneficial effects of water and inoculum supply were evident, resulting in an immediate growth of the biogas yield, with increasing gas generation rates at higher temperature. On the one hand, the supplemental water addition may have reduced the inhibitory effect by diluting potential toxic substances such as heavy metals (copper, chromium or zinc), ammonia and VFAs. (Chen et al., 2008; Yenigun and Demirel, 2013; Poggi-Varaldo et al., 1997). On the other hand, a proper balance between acidogens and methanogens could have been achieved by lowering the organic load (through waste removal) and increasing the active bacteria mass within the anaerobic reactors (through inoculum addition). Indeed, tests at $55^{\circ} \mathrm{C}$ achieved the asymptotical value of $66.7 \pm 6.3 \mathrm{NI} \mathrm{CH}_{4} / \mathrm{kgTS}$ and $50.0 \pm 2.3 \mathrm{NI}$ $\mathrm{CO}_{2} / \mathrm{kgTS}$ within 30-40 days after the inoculum and water addition. In tests performed at $37{ }^{\circ} \mathrm{C}$, a cumulative volume of $73.1 \pm 2.1 \mathrm{NI} \mathrm{CH}_{4} / \mathrm{kgTS}$ and $54.9 \pm 1.8 \mathrm{NI} \mathrm{CO} / \mathrm{kgTS}$ was measured after $60-70$ days from inoculum and water supply. These results showed that the biodegradability of the MBT waste in terms of methane and carbon dioxide yields did not vary significantly between $37{ }^{\circ} \mathrm{C}$ and $55{ }^{\circ} \mathrm{C}$ when moisture conditions were not limiting, as also observed by other authors (Hejnfelt and Angelidaki, 2009; Liu et al., 2009; Veeken and Hamelers 1999). In fact, in both cases, the total biogas yield at the end of these tests was in the range of 55-60\% of the methane potential value (66.7 and 73.1 against $121 \mathrm{Nl} \mathrm{CH}_{4} / \mathrm{kgTS}$ ). However, from the results obtained at room temperature, it is evident that the temperature surely affects the gas generation rate but also seems to influence the gas generation capacity. Indeed, in test with water and inoculum addition (see R2 test in Fig. 2), the gas production achieved a value of $8.5 \pm 1.0 \mathrm{NI} \mathrm{CH}_{4} / \mathrm{kgTS}$ and $19.3 \pm 0.3 \mathrm{Nl} \mathrm{CO}_{2} / \mathrm{kgTS}$ after 70 days from inoculum addition but was still increasing, indicating that the stable methanogenic phase has not been reached yet (see Fig. S1 in the Supplementary information).

\subsection{Estimation of biogas kinetic constants}

Fig. 5 shows, for the tests that achieved the stable methanogenic phase, the cumulative biogas production simulated with the first-order kinetic model (lines) fitted to the measured data (dots). The best-fit 
parameters used in the model are reported in Table 5. Making reference to Fig. 5, it can be noticed that, in all cases, the first-order kinetic model accurately reproduces the different shapes of accumulated gas volume curves, as confirmed by the $\mathrm{R}^{2}$ values reported in Table 5 . Modelling the experimental results revealed that the biodegradability of the MBT waste, which is expressed as ratio of cumulative gas volume to potential gas ( $\% \mathrm{~L}_{0} / \mathrm{BMP}$ ), ranged between $56 \%$ to $75 \%$ in tests at $75 \% \mathrm{w} / \mathrm{w}$ water content and decreased to $34 \%$ in tests with water content at field capacity and without inoculum addition. This range is slightly lower than the typical values for solid state incubation tests of MBT residues, presumably due to the poor stability degree of the MBT waste analysed in this study. For example, Binner and Zach (1999) found that the gas generated within 90 days was about $75 \%$ to $90 \%$ of the potential gas generation capacity (e.g. gas volume measured after 240 days) for well treated wastes (duration of pre-treatment $>10$ weeks).

Fig. 5

As already discussed above, higher operative temperature leads to a faster gas generation since temperature enhances both microbial growth and activity (Bouallagui et al., 2005; Gavala et al., 2003; Kim et al., 2002). Specifically, k-values vary from $0.007 \mathrm{~d}^{-1}$ at room temperature, $0.03-0.05 \mathrm{~d}^{-1}$ at $37^{\circ} \mathrm{C}$ and $0.04-$ $0.11 \mathrm{~d}^{-1}$ at $55^{\circ} \mathrm{C}$. Moreover, a linear correlation of k-values with the operative temperature was observed for tests at $75 \% \mathrm{w} / \mathrm{w}$ water content.

These k-values were also used to estimate the time required to reach the $99 \%$ of the maximum biogas generation $L_{0}$, as follows:

$T_{99 \%}=\frac{\ln (1-0.99)}{k}$

Due to quite high k-values, a relatively short time period $\mathrm{T}_{99 \%}$ (Table 5), ranging from few months up to 2 years, was computed.

\section{Table 5}

Table 6 reports a brief literature review of the kinetic constants and gas yields experimentally determined for different types of organic substrates. As shown in Table 6, these parameters vary substantially between different substrates, experimental procedures and tests conditions. Even if a direct comparison is not possible, the k-values obtained in this work are in line with most of these studies. For instance, the k-value 
of $0.007 \mathrm{~d}^{-1}$ determined at $\mathrm{T}=20-25{ }^{\circ} \mathrm{C}$ and water content of $75 \% \mathrm{w} / \mathrm{w}$, is consistent with the results obtained by Vavilin et al. (2004) for MSW waste at $65 \%$ of water content and $T=30^{\circ} \mathrm{C}\left(\mathrm{k}=0.007-0.08 \mathrm{~d}^{-1}\right)$. Similarly, the k-values range $\left(0.028-0.054 \mathrm{~d}^{-1}\right)$ observed at $37^{\circ} \mathrm{C}$ appears close to the one reported by Neves et al. (2006), which refer to a co-digestion of organic waste and sewage sludge $\left(0.035-0.063 \mathrm{~d}^{-1}\right)$. On the contrary, significant differences can be observed referring to the results presented by De Gioannis et al. (2009) and Mou et al. (2015). Indeed, the k-values reported by those authors are up to one-two orders of magnitude lower than the ones obtained in this work. This difference can be due to the higher content of readily degradable organic matter in the analysed MBT waste compared to the low-organic wastes of Mou et al. (2015) and De Gioannis et al. (2009).

Nevertheless, it should be kept in mind that the high water content ( $75 \% \mathrm{w} / \mathrm{w})$ as well as the inoculum addition had accelerated the biodegradation process during the anaerobic experiments. Hence, the gas generation rate and yield listed in Table 5 may be overestimated in comparison to real landfill conditions where the emplaced MBT wastes will not be able to retain the high water content $(75 \% \mathrm{w} / \mathrm{w})$ simulated in lab scale tests. For example, Heyer et al. (2013) stated that the biological conversion process within lysimeters filled with MBT waste could be accelerated by a factor 3-10 compared to MBT landfills due to water addition or leachate recirculation.

\subsection{Inhibition of anaerobic digestion process}

Analysis carried out on the MBT waste samples removed from the reactors at the different stages of the tests revealed that $\mathrm{pH}$ was still suitable for the anaerobic digestion (6.6-7.0). Hence, in this specific case, $\mathrm{pH}$ alone did not give a clear indication of process inhibition. However, it should be considered that $\mathrm{pH}$ changes may be very small in highly buffered system even when the process is severely stressed (Ahring et al., 1995). Thus, it is likely that $\mathrm{pH}$ was buffered due to contrasting effects of VFAs accumulation, which could have led to acidic conditions, and proteins degradation that could have favoured an increase of waste buffer capacity through the ammonia release (Veeken et al., 2000). In fact, as shown in Table 7, high VFAs and ammonia concentrations were measured in all MBT samples. Specifically, Table 7 reports the average 
values of total TKN and soluble nitrogen $\mathrm{NH}_{4}-\mathrm{N}$, the ratio between $\mathrm{NH}_{4}-\mathrm{N}$ and TKN, and the total VFAs concentration measured in the fresh MBT sample and in the MBT samples removed from the anaerobic batch experiments carried out at room temperature (R2), at $37{ }^{\circ} \mathrm{C} \mathrm{(T2A} \mathrm{and} \mathrm{T3)} \mathrm{and} 55^{\circ} \mathrm{C}$ (T6A and T7). As shown in this table, the ratio of $\mathrm{NH}_{4}-\mathrm{N} / \mathrm{TKN}$ exhibited a twofold increase compared to what measured in the fresh waste. Moreover, VFAs concentrations in all samples were more than one order of magnitude higher than the ones measured in the fresh sample. These results indicate that the analysed MBT waste still contains a certain amount of readily and medium-degradable organic matter, which was not expected, since the easily degradable fraction was supposed to be mineralised during the stabilization process in the MBT plant. The high biological reactivity of this MBT waste may be in part due to a limited efficiency, during the waste sampling campaign, of the aerobic decomposition process employed in this specific MBT plant. However, as also highlighted in previous researches, this poor stabilisation can be mainly ascribed to the fact that the wastes coming out from this plant are not subjected to a further ripening treatment that might be necessary in order to obtain a well stabilized waste with lower impacts in landfills (Di Lonardo et al., 2014). Referring to Table 7, it can also be noticed that total VFAs content, as well as ammonia, exhibited an increasing trend with temperature $(T 7, T 6>T 3, T 2>R 2)$ reflecting the different extent of the biological process reached at different operating conditions. Namely, a total VFAs content ranging from 5.4 to $7.9 \mathrm{~g} / \mathrm{l}$ was measured and the acetate was found as the predominant compound (see Table S1 in supplementary information). Hence, it seems that the hydrolytic-acidogenic bacteria did not limit the substrate degradation and the process was held at the acetogenic and methanogenic stage (a similar result was obtained by Palatsi et al., 2011). Therefore, the inhibition was likely due to an imbalance in the growth rate of acidogenic bacteria, which led to an accumulation of degradation by-products in reactors, as also observed by Adani et al. (2004). On the other hand, the inhibition of methanogenic bacteria may be also due to the high TKN and ammonia content observed in the MBT samples (see Table 7). Thus, it is likely that the interaction between ammonia, VFA and $\mathrm{pH}$ could have led to an "inhibited steady state" condition in which the process was running stably but a very low methane yield (Chen et al., 2008). 


\subsection{Experimental findings and practical implications}

537 The BMP experiments, performed under optimal operating conditions, highlighted that for the analysed 538 MBT waste, only $45 \%$ of the theoretical gas generation potential can be achieved within 30 days. This may 539 be due to the presence of less soluble/degradable or more recalcitrant organic substances in the solid 540 matrix, which cannot be mineralized during the limited duration of the BMP experiment. Hence, BMP tests, 541 with respect to a simple stoichiometric estimation from the organic carbon measured in the solid matrix, 542 can provide useful indications on the expected potential gas generation capacity of landfilled waste under 543 optimal conditions. On the contrary, the results obtained in this study highlighted that particular caution 544 should be paid when the anaerobic batch tests are carried out under limiting operational conditions, e.g. 545 low water content and temperature, high organic load, no inoculum addition. This is particularly true when 546 the material of concern is, as in the present case, a waste with high organic matter content and a poor 547 stability degree. In fact, although the tests performed under these limiting conditions may better resemble 548 the environmental conditions expected in the field, the presence of inhibitory substances at high level (such as ammonia, VFA, heavy metals) may slow down or stop the anaerobic microbial process leading to an underestimation of the gas yield and generation rate. Indeed, as already shown in Table 7, in all experiments which exhibited very low gas generation rate and methane content, high concentrations of VFA and ammonia were measured within the systems, revealing an imbalanced kinetic between acid forming and acid consuming bacteria. Nevertheless, small pH changes were detected due to high protein degradation, which have increased buffer capacity of the analysed waste sample as a result of ammonia release. Hence, it is likely that the interaction between ammonia, VFA and pH lead to an "inhibited steady state" condition in which the anaerobic process may run stably but at a very low gas yield. In particular, the experimental results suggested that the microbial activity could be completely inhibited when the water content of MBT waste was less than $32 \%$ (on wet weight) and severely reduced for higher water content (up to the field capacity of approximately $43 \%$ ) depending on the operating temperature. These findings suggest that a stable gas generation process could be delayed for a long time until the environmental conditions within MBT waste landfills become favourable to the establishment of a stable methanogenic 
activity. Thus, it is not possible to predict how long the lag-phase can last in a landfill disposal scenario, where the boundary conditions significantly vary depending on the climate, the landfill geometry (surface, height), the operative management strategies in place (e.g. leachate recirculation, waste disposal methods), the presence and type of temporary and final cover systems. Indeed, the experimental results reported in this study revealed that, as soon as the anaerobic process starts, a relative short time period, ranging from few months up to two years depending on the water content and temperature, is required to deplete the gas generation capacity. However, small scale experiments performed under controlled conditions may not provide a gas generation trend that is completely representative of full-scale landfill sites. Here, higher heterogeneous and variable conditions are expected due to greater amounts of waste mass, miscellaneous nature of emplaced waste as well as the heterogeneity of water flow patterns inside the landfill body that are also affected by operational strategies (such as waste emplacement density, permeability and thickness of daily cover). Moreover, landfilled waste are subjected to increasing overloading pressure due to the emplacement of new waste layers. This condition surely influences the water retention capacity of landfilled MBT waste so that the water content will be surely lower than the ones simulated in the lab scale tests (e.g. $75 \% \mathrm{w} / \mathrm{w}$ ). This implies that the gas generation, in terms of both gas yield and rate, measured in anaerobic experiments at high water contents may be significantly higher than what expected in real scale MBT waste landfills.

\section{Conclusions and perspectives}

The gas production from MBT wastes was analysed by performing anaerobic batch tests under different operating conditions. In order to characterize the MBT material regarding its long-term gas emission in different landfill disposal scenarios, a wide range of water contents (26-43\%w/w up to $75 \% \mathrm{w} / \mathrm{w}$ ) and temperatures $\left(20-25{ }^{\circ} \mathrm{C}, 37^{\circ} \mathrm{C}\right.$ and $\left.55^{\circ} \mathrm{C}\right)$ were investigated. The obtained results suggest that the analysed MBT material still contains a large amount of readily degradable organic matter, as confirmed by the long duration of the lag-phase (several months), the high values of gas production potential (199.2 $\pm 63 \mathrm{Nml} / \mathrm{gTS})$, the gas generation rates (ranging from $0.007 \mathrm{~d}^{-1}$ at room temperature, $0.03-0.05 \mathrm{~d}^{-1}$ at $37^{\circ} \mathrm{C}$ and $0.04-0.11$ 
$587 \mathrm{~d}^{-1}$ at $55^{\circ} \mathrm{C}$ ), as well as by the strong inhibition effects observed due to high concentrations of VFAs and 588 soluble ammonia.

589 Based on the results presented in this paper, the following conclusions and perspectives can be drawn:

$590 \quad-\quad$ it is very difficult to predict how long the lag-phase can last in MBT waste landfills where the 591 boundary conditions change continuously and vary significantly depending on the climate, the systems.

- The water content of emplaced MBT waste is the most important factor limiting the anaerobic biological process. Experimental results showed that when the moisture was lower than $32 \% \mathrm{w} / \mathrm{w}$, the methanogenic microbial activity was completely inhibited whereas for higher values $(43 \% \mathrm{w} / \mathrm{w})$ only a limited amount of the degradable organic matter was converted to biogas ( $34 \%$ of the potential gas generation capacity).

- As soon as the environmental conditions inside the waste mass become favourable to the establishment of the stable methanogenic phase, a relatively short time period, ranging from few months up to two years is required to deplete the MBT waste gas generation. However, this result provides just an indication of the actual lifetime of biogas production from MBT wastes disposed of in landfills, where much higher amount of waste are emplaced and the environmental conditions may be quite far from the experimental ones.

- The benefits of using the MBT technology within a sustainable waste management system strongly depends on the efficiency of the biostabilization process in reducing the gas generation capacity of the residual MBT waste. In this specific case, experimental data suggest that the aerobic biological treatment carried out in this specific MBT facility was not properly managed and did not guarantee a sufficient degree of stability for the produced MBT waste. Therefore, a further treatment of this MBT waste might be desirable before landfilling it. 
The authors wish to thank Hector Garcia and Hector Diaz, laboratory of Technical University of Denmark, 614 for the valuable cooperation to the chemical-physical analysis.

\section{References}

Adani, F., Tambone, F., Gotti, A., 2004. Biostabilization of municipal solid waste. Waste Manage. 24, 775783.

Ahring, B.K., Sandberg, M., Angelidaki, I., 1995. Volatile fatty acid as indicators of process imbalance in anaerobic digestors. Appl. Microbiol. Biotechnol. 43, 559-565.

Angelidaki, I., Sanders, W., 2004. Assessment of the anaerobic biodegradability of macropollutants. Rev. Environ. Sci. and BioTechnol. 3, 117-129.

Angelidaki, I., Alves, M., Bolzonella, L., Borzacconi, L., Campos, J.L., Guwy, A.J., Kalyuzhnyi, S., Jenicek, P., van Lier, J.B., 2009. Defining the biomethane potential (BMP) of solid organic wastes and energy crops: a proposed protocol for batch assays. Water Sci. Technol. 59, 927-934.

Amani, T., Nosrati, M., Sreekrishnan, T.R., 2011. A precise experimental study on key dissimilarities between mesophilic and thermophilic anaerobic digestion of waste activated sludge. Int. J. Environ. Res. 5, 333-342.

Argun, H., Kargi, F., Kapdan, I.K., 2008. Light fermentation of dark fermentation effluent for bio-hydrogen production by different Rhodobacter species at different initial volatile fatty acid (VFA) concentrations. Int. J. Hydrogen Energ. 33, 7405-7412. 
Bayard, R., de Araújo Morais, J., Ducom, G., Achour, F., Rouez, M., Gourdon, R., 2010. Assessment of the effectiveness of an industrial unit of mechanical-biological treatment of municipal solid waste. J. Hazard. Mater. 175, 23-32.

Bilgili, M.S., Demir, A., Varank, G., 2009. Evaluation and modeling of biochemical methane potential (BMP) of landfilled solid waste: a pilot scale study. Bioresource Technol. 100, 4976-4980.

Binner, E., Zach, A., 1999. Laboratory tests describing the biological reactivity of pretreated residual wastes. In: ORBIT Symposium, Weimar, 1999.

Bogner, J., Pipatti, R., Hashimoto, S., Diaz, C., Mareckova, K., Diaz, L., Kjeldsen, P., Monni, S., Faaij, A., Gao, Q., Zhang, T., Ahmed, M.A., Sutamihardja, R.T., Gregory, R., 2008. Mitigation of global greenhouse gas emissions from waste: conclusions and strategies from the Intergovernmental Panel on Climate Change (IPCC) Fourth Assessment Report. Working Group III (Mitigation). Waste Manage. Res. 26, 11-32.

Boldrin, A., Neidel, T.,L., Damgaard, A., Bhander, G.S., Møller, J., Christensen, T.H., 2011. Modelling of environmental impacts from biological treatment of organic municipal waste in EASEWASTE. Waste Manage. 31, 619-630.

Borzacconi, L., Lápez, I., Anido, C., 1997. Hydrolysis constant and VFA inhibition in acidogenic phase of MSW anaerobic degradation. Water Sci. Technol. 36, 479-484.

Bouallagui, H., Touhami, Y., Ben Cheick, R., Hamdi, M., 2005. Bioreactor performance in anaerobic digestion of fruit and vegetables wastes. Process Biochem. 40, 989-995.

Braber, K., 1995. Anaerobic digestion of municipal solid waste: a modern waste disposal option on the verge of breakthrough. Biomass Bioenerg. 9, 365-376.

Cabbai, V., Ballico, M., Aneggi, E., Goi, D., 2013. BMP tests of source selected OFMSW to evaluate anaerobic codigestion with sewage sludge. Waste Manage. 33, 1626-1632. 
656

657

Chen, Y., Cheng, J.J., Creamer, K.S., 2008. Inhibition of anaerobic digestion process: a review. Bioresource Technol. 99, 4044-4064.

De Araujo-Morais, J., Ducom, G., Achour, F., Rouez, M., Bayard, R., 2008. Mass balance to assess the efficiency of a mechanical-biological treatment. Waste Manage. 28, 1791-1800.

De Gioannis, G., Muntoni, A., Cappai, G., Milia, S., 2009. Landfill gas generation after mechanical biological treatment of municipal solid waste. Estimation of gas generation rate constants. Waste Manage. 29, 10261034.

Di Lonardo, MC, Binner, E., Lombardi, F., 2014. Investigation on biological stability degree of mechanicallybiologically pre-treated MSW produced in Rome. In: Eurasia Waste Management Symposium.

Di Maria, F., Sordi, A., Micale, C., 2013. Experimental and life cycle assessment analysis of gas emission from mechanically-biologically pretreated waste in a landfill with energy recovery. Waste Manage. 33, 2557-2567.

Donovan, S.M., Bateson, T., Gronow, J.R., Voulvoulis, N., 2010. Modelling the behaviour of mechanical biological treatment outputs in landfills using the GasSim model. Sci. Total Environ. 408, 1979-1984.

Elbeshbishy, E., Nakhla, G., Hafez, H., 2012. Biochemical methane potential (BMP) of food waste and primary sludge: influence of inoculum pre-incubation and inoculum source. Bioresource Technol. 110, 1825.

Esposito, G., Frunzo, L., Liotta, F., Panico, A., Pirozzi, F., 2012. Bio-methane potential tests to measure the biogas production from the digestion and co-digestion of complex organic substrates. The Open Environmental Engineering Journal 5, 1-8.

Farrell, M., Jones, D.L., 2009. Critical evaluation of municipal solid waste composting and potential compost markets. Bioresource Technol. 100, 4301-4310. 
678 Gavala, H.N., Yenal, U., Skiadas, V., Westermann, P., Ahring, B.K., 2003. Mesophilic and thermophilic 679 anaerobic digestion of primary and secondary sludge. Effect of pre-treatment at elevated temperature. 680 Water Res. 37, 4561-4572.

681 Ghatak, M.D., Mahanta, P., 2014. Effect of temperature on biogas production from lignocellulosic 682 biomasses. In: International Conference on Non Conventional Energy (ICONCE 2014).

683 Gunaseelan, V.N., 1997. Anaerobic digestion of biomass for methane production: a review. Biomass 684 Bioenerg. 13, 83-114.

685 Hansen, T.,L., Schmidt, J.E., Angelidaki, I., Marca, E., Jansen, J.C., Mosbæk, H., Christensen, T.H., 2004. 686 Method for determination of methane potentials of solid organic waste. Waste Manage. 24, 393-400.

687

688 689 690 691 692 693

Harborth, P., Fuß, R., Münnich, K., Flessa, H., Fricke, K., 2013. Spatial variability of nitrous oxide and methane emissions from an MBT landfill in operation: strong $\mathrm{N}_{2} \mathrm{O}$ hotspots at working face. Waste Manage. 33, 2099-2107.

Hejnfelt, A., Angelidaki, I., 2009. Anaerobic digestion of slaughterhouse by-products. Biomass Bioenerg. 33, 1046-1054.

Heyer, K.U., Hupe, K., Stegmann, R., 2013. Methane emissions from MBT landfills. Waste Manage. 33, 18531860.

Khalid, A., Arshad, M., Anjum, M., Mahmood, T., Dawson, L., 2011. The anaerobic digestion of solid organic waste. Waste Manage. 31, 1737-1744.

Kim, M., Ahn,Y-H. Speece, R.E., 2002. Comparative process stability and efficiency of anaerobic digestion; mesophilic vs thermophilic. Water Res. 36, 4369-4385.

Labatut, R.A., Angenent, L.T., Scott, N.R., 2011. Biochemical methane potential and biodegradability of complex organic substrates. Bioresource Tehnol. 102, 2255-2264. 
Laner, D., Crest, M., Scharff, H., Morris, J.W.F., Barlaz, M.A., 2012. A review of approaches for the long-term management of municipal solid waste landfills. Waste Manage. 32, 498-512.

Lesteur, M., Bellon-Maurel, V., Gonzalez, C., Latrille, E., Roger, J.M., Junqua, G., Steyer, J.P., 2010. Alternative methods for determining anaerobic biodegradability: a review. Process Biochem. 45, 431-440.

Li, Y., Park, S.Y., Zhu, J., 2011. Solid-state anaerobic digestion for methane production from organic waste. Renew. Sust. Energ. Rev. 15, 821-826.

Liotta, F., d'Antonio, G., Esposito, G., Fabbricino, M., Frunzo, L., van Hullebusch, E.,D., Lens, P.N.L., Pirozzi, F., 2014. Effect of moisture on disintegration kinetics during anaerobic digestion of complex organc substrates. Waste Manage. Res. 32, 40-48.

Liu, G., Zhang, R., El-Mashad, H.M., Dong, R., 2009. Effect of feed to inoculum ratios on biogas yields of food and green wastes. Bioresource Tehnol. 100, 5103- 5108.

Lo, H.M., Kurniawan, T.A., Sillanpää, M.E.T., Pai, T.Y., Chiang, C.F., Chao, K.P., Liu, M.H., Chuang, S.H., Banks, C.J., Wang, S.C., Lin, C.Y., Liu, W.F., Cheng, P.H., Chen, C.K., Chiu, H.Y., Wu, H.Y., 2010. Modeling biogas production from organic fraction of MSW co-digested with MSWI ashes in anaerobic bioreactors. Bioresource Tehnol. 101, 6329-6335.

Lornage, R., Redon, E., Lagier, T., Hébé, I., Carré, J., 2007. Performance of a low cost MBT prior to landfilling: study of the biological treatment of size reduced MSW without mechanical sorting. Waste Manage. 27, $1755-1764$.

Mata-Alvarez, J., Cecchi, F., Pavan, P., Llabres, P., 1990. The performances of digesters treating the organic fraction of municipal solid wastes differently sorted. Biol. Waste. 33, 181-199.

Mata-Alvarez, J., Macé, S., Llabrés, P., 2000. Anaerobic digestion of solid organic wastes. An overview of research achievements and perspectives. Bioresource Tehnol. 74, 3-16. 
Modin, H., 2007. Impact of pre-treatment on the stability and leachability of three different wastes. PhD dissertation. Lund University.

Mohajer, A., Trémier, A., Barrington, S., Téglia, C., 2010. Compost mixture influence of interactive physical parameters on microbial kinetics and substrate fractionation. Waste Manage. 30, 1464-1471.

Montejo, C., Tonini, D., Márquez, M.C., Astrup, T.F., 2013. Mechanical-biological treatment: performance and potentials. An LCA of 8 MBT plants including waste characterization. J. Environ. Manage. 128, 661-673.

Mor, S., Ravindra, K., De Visscher, A., Dahiya, R.P., Chandra, A., 2006. Municipal solid waste characterization and its assessment for potential methane generation: a case study. Sci. Total Environ. 371, 1-10.

Mora-Naranjo, N., Meima, J.A., Haarstrick, A., Hempel, D.C., 2004. Modelling and experimental investigation of environmental influences on the acetate and methane formation in solid waste. Waste Manage. 24, 763-773.

Mou, Z., Scheutz, C., Kjeldsen, P., 2015. Evaluating the methane generation rate constant (k value) of low organic waste at Danish landfills. Waste Manage. 35, 170-176.

Mshandete, A., Björnsson, L., Kivasi, A.K., Rubindamayugi, M.S.T., Mattiasson, B., 2006. Effect of particle size on biogas yield from sisal fibre waste. Renew. Energ. 31, 2385-2392.

Neves, L., Oliveira, R., Alves, M.M., 2006. Anaerobic co-digestion of coffee waste and sewage sludge. Waste Manage. 26, 176-181.

Nopharatana, A., Pullammanappallil, P.C., Clarke, W., 2007. Kinetics and dynamic modelling of batch anaerobic digestion of municipal solid waste in a stirred reactor. Waste Manage. 27, 595-603.

Palatsi, J., Viñas, M., Guivernau, M., Fernandez, B., Flotats, X., 2011. Anaerobic digestion of slaughterhouse waste: main process limitations and microbial community interactions. Bioresource Tehnol. 102, 22192227. 
Pan, J., Voulvoulis, N., 2007. The role of mechanical and biological treatment in reducing methane emissions from landfill disposal of municipal solid waste in the United Kingdom. J. Air Waste Manage. 57, 155-163.

Pantini, S., Verginelli, I., Lombardi, F., 2014. A new screening model for leachate production assessment at landfill sites. Int. J. Environ. Sci. Technol. 11, 1503-1516.

Pantini, S., Verginelli, I., Lombardi, F., 2015. Analysis and modeling of metals release from MBT wastes through batch and up-flow column tests. Waste Manage. 38, 22-32.

Poggi-Varaldo, H.M., Rodríguez-Vázquez, R., Fernández-Villagómez, G., Esparza-García, F., 1997. Inhibition of mesophilic solid-substrate anaerobic digestion by ammonia nitrogen. Appl. Microbiol. Biotechnol. 47, 284-291.

Pognani, M., Barrena, R., Font, X., Scaglia, B., Adani, F., Sánchez, A., 2010. Monitoring the organic matter properties in a combined anaerobic/aerobic full-scale municipal source separated waste treatment plant. Bioresource Tehnol. 101, 6873-6877.

Raposo, F., de la Rubia, M.A., Borja, R., Alaiz, M., 2008. Assessment of a modified and optimised method for determining chemical oxygen demand of solid substrates and solutions with high suspended solid content. Talanta 76, 448-453.

Raposo, F., De la Rubia, M.A., Fernández-Cegrí, V., Borja, R., 2011. Anaerobic digestion of solid organic substrates in batch mode: an overview relating to methane yields and experimental procedures. Renew. Sust. Energ. Rev. 16, 861-877.

Scaglia, B., Confalonieri, R., D'Imporzano, G., Adani, F., 2010. Estimating biogas production of biologically treated municipal solid waste. Bioresource Tehnol. 101, 945-952.

Schievano, A., D'Imporzano, G., Malagutti, L., Fragali, E., Ruboni, G., Adani, F., 2010. Evaluating inhibition conditions in high-solids anaerobic digestion of organic fraction of municipal solid waste. Bioresource Technol. 101, 5728-5732. 
Siddiqui, A.A., Richards, D.J., Powrie, W., 2013. Biodegradation and flushing of MBT wastes. Waste Manage. $33,2257-2266$.

Sormunen, K., Einola, J., Ettala, M., Rintala, J., 2008. Leachate and gaseous emissions from initial phase of landfilling mechanically and mechanically-biologically treated municipal solid waste residuals. Bioresource Tehnol. 99, 2399-2409.

Thomsen, N.I., Milosevic, N., Bjerg, P.L., 2012. Application of a contaminant mass balance method at an old landfill to assess the impact on water resources. Waste Manage. 32, 2406-2417.

Tremier, A., de Guardia, A., Massiani, C., Paul, E., Martel, J.L., 2005. A respirometric method for characterising the organic composition and biodegradation kinetics, for a mixture of sludge and bulking agent to be co-composted. Bioresource Technol. 96, 169-180.

UNI EN 12457-2, (2004). Characterization of waste - Leaching - Compliance test for leaching of granular waste materials and sludges. Part 4: One stage batch test at a liquid to solid ratio of $10 \mathrm{l} / \mathrm{kg}$ for materials with particle size below $4 \mathrm{~mm}$ (without or with size reduction).

UNI EN 13137, (2001). Characterization of waste - Determination of total organic carbon (TOC) in waste, sludges and sediments.

UNI 10802, (2013). Rifiuti - Campionamento manuale, preparazione del campione ed analisi degli eluati. Wastes- Manual sampling and preparation of sample and analysis of eluates.

UNI/TS 11184, (2006). Rifiuti e combustibili ricavati da rifiuti - Determinazione della stabilità biologica mediante I'Indice di Respirazione Dinamico (IRD). Waste and refuse derived fuel - Determination of biological stability by dynamic respirometric index.

UNI EN 14346 (2006). Characterization of waste - Calculation of dry matter by determination of dry residue or water content. 
van Lier, J.B., Rebac, S., Lettinga, G., 1997. High-rate anaerobic wastewater treatment under psychrophilic and thermophilic conditions. Wat. Sci. Tech. 35, 199-206.

Vavilin, V.A., Lokshina, L.Y., Jokela, J.P.Y., Rintala, J.A., 2004. Modeling solid waste decomposition. Bioresource Tehnol. 94, 69-81.

Vavilin, V.A., Fernandez, B., Palatsi, J., Flotats, X., 2008. Hydrolysis kinetics in anaerobic degradation of particulate organic material: an overview. Waste Manage. 28, 939-951.

Veeken, A., Hamelers, B., 1999. Effect of temperature on hydrolysis rates of selected biowaste components. Bioresource Tehnol. 69, 249-254.

Veeken, A., Kalyuzhnyi, S., Scharff, H., Hamelers, B., 2000. Effect of pH and VFA on hydrolysis of organic solid waste. J. Environ. Eng. 126, 1076-1081.

Vigneron, V., Bureau, C., Bernet, N., Bouchez, T., 2007. Effect of ammonia on the methanogenic diversity and activity in simulated MSW bioreactor landfills. In: Proceedings Sardinia 2007, Cagliari, Italy.

White, J.K., Beaven, R.P., 2013. Developments to a landfill processes model following its application to two landfill modelling challenges. Waste Manage. 33, 1969-1981.

Yenigün, O., Demirel, B., 2013. Ammonia inhibition in anaerobic digestion: a review. Process Biochem. 48, 901-911.

Zach, A., Binner, E., Latif, M., 2000. Improvement of municipal solid waste quality for landfilling by means of mechanically-biological pretreatment. Waste Manage. Res. 18, 25-32. 
809 Fig. 1. BMP cumulative methane production measured in control (red dots) and MBT waste (green dots) tests, 810 expressed as $\mathrm{Nml} \mathrm{CH}_{4}$ per g of total solids. Solid red line: theoretical methane generation of control. Dotted green line: 811 theoretical methane generation of MBT waste, computed according to Eq. (3). Bars: standard deviation. The results is 812 the average of 6 and 3 bottles for MBT waste and controls, respectively.

813 Fig. 2. Cumulative methane (red circles) and carbon dioxide (black square dots) curves as a function of the incubation 814 time, obtained during anaerobic batch tests carried out on MBT waste samples at room temperature (20-25 $\left.{ }^{\circ} \mathrm{C}\right)$ and 815 different values of initial water content (26\%, 34-75\% and 43\% w/w). Solid red line: $\mathrm{CH}_{4}$ potential obtained from BMP 816 tests. Dotted black line: $\mathrm{CO}_{2}$ potential obtained from BMP tests. Dotted grey line: starting point of stage III.

817 Fig. 3. Cumulative methane (red circles) and carbon dioxide (black square dots) curves as a function of the incubation 818 time, obtained during anaerobic batch tests carried out on MBT waste samples at $37^{\circ} \mathrm{C}$ and different values of the 819 initial water content $\left(26 \%, 32 \%, 32-75 \%, 38-75 \%, 43 \%\right.$ and $43-48 \%$ w/w). Solid red line: $\mathrm{CH}_{4}$ potential from $\mathrm{BMP}$. 820 Dotted black line: $\mathrm{CO}_{2}$ potential from BMP. Solid grey line: starting point of stage II. Dotted grey line: starting point of 821 stage III.

822 Fig. 4. Cumulative methane (red circles) and carbon dioxide (black square dots) curves as a function of the incubation 823 time, obtained during anaerobic batch tests carried out on MBT waste samples at $55{ }^{\circ} \mathrm{C}$ and different values of the 824 initial water content $(26 \%, 32 \%, 32-75 \%, 38-75 \%, 43 \% \mathrm{w} / \mathrm{w})$.

825 Fig. 5. Cumulative biogas volume ( $\mathrm{NI} / \mathrm{kgTS}$ ) as a function of the incubation time: comparison between measured data 826 (dots) and modelling results obtained with a first-order kinetic model (lines). 


\section{LIST OF TABLES}

828 Table 1. Literature overview on the anaerobic digestion experiments performed on MBT wastes.

829 Table 2. Average composition of residual MSW (\% wet weight) feeding the MBT plant.

830 Table 3. Summary of the test conditions and activity stage of the anaerobic batch experiments performed on the MBT

831 waste samples.

Table 4. Characterization of the MBT waste. Mean value \pm standard deviation.

833 Table 5. First-order kinetic model parameters derived by interpolating experimental data for different test conditions. $\mathrm{L}_{0}$ : maximum biogas production ( $\left.\mathrm{Nl} / \mathrm{kgTS}\right)$. $\mathrm{t}_{\text {lag }}$ : lag time $(\mathrm{d})$. $\mathrm{k}$ : first-order kinetic constant $\left(\mathrm{d}^{-1}\right)$. $\mathrm{R}^{2}$ : correlation factor. $835 \% \mathrm{~L}_{0} / \mathrm{BMP}$ : percentage of gas generated compared to the potential value measured in BMP test. $\mathrm{T}_{99 \%}$ : time to reach 99\% of maximum gas generation.

837 Table 6. Literature values of gas yield and first-order kinetic constant ( $k$ ) for different types of organic substrates.

838 Table 7. Average value and $( \pm)$ standard deviation of total nitrogen, $\mathrm{TKN}(\mathrm{g} / \mathrm{kgTS})$, soluble nitrogen, $\mathrm{NH}-\mathrm{N}(\mathrm{g} / \mathrm{kgTS})$, $839 \% \mathrm{NH}_{4}-\mathrm{N} / \mathrm{TKN}$ and total VFAs concentration $(\mathrm{g} / \mathrm{l})$ measured in fresh MBT waste and in samples removed from 840 anaerobic batch reactors. 
Table 1 (Line 94)

\begin{tabular}{|c|c|c|c|c|c|c|c|}
\hline Reference & Amount & Particle size & Water addition & Inoculum & Temperature $\left({ }^{\circ} \mathrm{C}\right)$ & Test duration (d) & Aim \\
\hline Binner and Zach (1999) & $50 \mathrm{~g}$ TS & $<20 \mathrm{~mm}$ & $\begin{array}{l}\text { 1I demineralized } \\
\text { water }\end{array}$ & Used & 35 & 42 & Cumulative gas \\
\hline De Araujo-Morais et al. (2008) & $20 \mathrm{~g}$ & $<20 \mathrm{~mm}$ & $\begin{array}{l}1.2 \text { I nutrient } \\
\text { medium }\end{array}$ & Used & 35 & 90 & Cumulative gas \\
\hline Sormunen et al. (2008) & $2 \mathrm{gVS}_{\mathrm{w}} / \mathrm{gVS}_{\text {in }}$ & $<40 \mathrm{~mm}$ & up to $95 \%$ & Used & $20-22$ & $70-100$ & Methane potential \\
\hline Barrena et al. (2008) & $200 \mathrm{~g}$ & ns & Not added & Used & 35 & 100 & $\begin{array}{c}\text { Gas production in solid } \\
\text { state test }\end{array}$ \\
\hline Barrena et al. (2008) & $1 \mathrm{~g}$ TS & $<1 \mathrm{~mm}$ & up to $50 \%$ & Used & 35 & 75 & $\begin{array}{l}\text { Gas production in } \\
\text { liquid state test }\end{array}$ \\
\hline Binner \& Zach (1999) & $1 \mathrm{~kg}$ TS & $<20 \mathrm{~mm}$ & $\begin{array}{l}\text { up to water holding } \\
\text { capacity }\end{array}$ & Not used & 40 & 90 & $\begin{array}{l}\text { Determining gas } \\
\text { generation in landfills }\end{array}$ \\
\hline De Gioannis et al. (2009) & $500 \mathrm{~g}$ & ns & $\begin{array}{l}\text { up to water holding } \\
\text { capacity }\end{array}$ & Not used & 30 & $240-390$ & $\begin{array}{l}\text { Modelling gas } \\
\text { generation }\end{array}$ \\
\hline Sormunen et al (2008) & $96 \mathrm{t}$ & $<40 \mathrm{~mm}$ & ns & Used & 40 & 640 & $\begin{array}{l}\text { Simulate landfill } \\
\text { emissions }\end{array}$ \\
\hline
\end{tabular}

ns=not specified

$\left.{ }^{*}\right)$ water added on wet weight basis

843

844

845 
Table 2 (Line 108)

\begin{tabular}{lcc}
\hline Categories & Mean & $S D$ \\
\hline Fines $<20 \mathrm{~mm}$ & 13.4 & 3.8 \\
Organic waste & 28.0 & 7.3 \\
Paper & 16.0 & 4.6 \\
Cardboard & 7.7 & 3.2 \\
Coupled packaging & 1.8 & 0.5 \\
Textiles & 3.0 & 1.1 \\
Diapers & 4.8 & 2.0 \\
Plastics & 14.4 & 2.8 \\
Rubber & 0.4 & 0.3 \\
Glass & 3.7 & 1.9 \\
Metals & 2.9 & 1.1 \\
Inert materials & 1.2 & 1.0 \\
Hazardous waste & 0.4 & 0.3 \\
Wood & 1.9 & 1.7 \\
Leather & 0.1 & 0.2 \\
Others & 0.4 & 0.4 \\
\hline
\end{tabular}


Table 3 (Line 250)

\begin{tabular}{|c|c|c|c|c|c|c|}
\hline ID TEST & $\begin{array}{l}\text { Reactor } \\
\text { volume } \\
\text { (l) } \\
\end{array}$ & $\left.\mathbf{T}^{\circ} \mathbf{C}\right)$ & $\begin{array}{l}\text { MBT weight } \\
\text { (kg TS) }\end{array}$ & $\begin{array}{l}\text { Water content } \\
(\% \mathrm{w} / \mathrm{w})\end{array}$ & Inoculum addition (g) & Duration (d) \\
\hline R1A, R1B & 12 & $20-25$ & 4.0 & $26 \%$ & Not used & Stage I: 167 \\
\hline R2A, R2B & 12 & $20-25$ & 4.4 & $\begin{array}{l}34 \% \text { (Stage I) } \\
75 \% \text { (Stage III) }\end{array}$ & $\begin{array}{l}\text { Stage III: } 800 \text { g mesophilic inoc. (TS=3.8\% wet weight, VS=60\%TS) + } \\
6.1 \text { kg water }{ }^{\text {(a) }}\end{array}$ & $\begin{array}{l}\text { Stage I: } 94 \\
\text { Stage III: } 73\end{array}$ \\
\hline R3A, R3B & 12 & $20-25$ & 4.5 & $43 \%$ & Not used & Stage I: 167 \\
\hline T1A, T1B & 1 & 37 & 0.37 & $26 \%$ & Stage II: 20 g mesophilic inoc. (TS=3.8\% wet weight, VS=60\%TS) & $\begin{array}{l}\text { Stage I: } 38 \\
\text { Stage II: } 94\end{array}$ \\
\hline T2A & 1 & 37 & 0.36 & $\begin{array}{l}32 \% \text { (Stage I) } \\
75 \% \text { (Stage III) }\end{array}$ & $\begin{array}{l}\text { Stage II: } 20 \text { g mesop. inoc. } \\
\text { Stage III: } 70 \text { g mesop. inoc. + } 530 \text { g water }{ }^{(\mathrm{b})}\end{array}$ & $\begin{array}{l}\text { Stage I: } 38 \\
\text { Stage II: } 20 \\
\text { Stage III: } 74 \\
\end{array}$ \\
\hline T2B & 1 & 37 & 0.37 & $32 \%$ & Stage II: 20 g mesop. inoc. (TS=3.8\% wet weight, VS=60\%TS) & $\begin{array}{l}\text { Stage I: } 38 \\
\text { Stage II: } 94\end{array}$ \\
\hline ТЗА, ТЗВ & 1 & 37 & 0.38 & $\begin{array}{l}38 \% \text { (Stage I) } \\
75 \% \text { (Stage III) }\end{array}$ & Stage III: 70 g mesop. inoc. +530 g water $^{(b)}$ & $\begin{array}{l}\text { Stage I: } 58 \\
\text { Stage III: } 74\end{array}$ \\
\hline T4A & 1 & 37 & 0.38 & $43 \%$ & Not used & Stage I: 132 \\
\hline T4B & 1 & 37 & 0.38 & $\begin{array}{l}43 \% \text { (Stage I) } \\
48 \% \text { (Stage III) }\end{array}$ & Stage III: 70 g mesop. Inoc. (same), no water addition ${ }^{(c)}$ & $\begin{array}{l}\text { Stage I: } 50 \\
\text { Stage III: } 82\end{array}$ \\
\hline T5A, T5B & 1 & 55 & 0.36 & $26 \%$ & Stage II: 20 g thermophilic inoc. (TS=3\% wet weight, VS=65\%TS) & $\begin{array}{l}\text { Stage I: } 24 \\
\text { Stage II: } 76\end{array}$ \\
\hline T6A & 1 & 55 & 0.36 & $\begin{array}{l}32 \% \text { (Stage I) } \\
75 \% \text { (Stage III) }\end{array}$ & $\begin{array}{l}\text { Stage II: } 20 \text { g thermop.inoc. } \\
\text { Stage III: } 70 \text { g thermop. inoc. + } 530 \text { g water (d) }\end{array}$ & $\begin{array}{l}\text { Stage I: } 24 \\
\text { Stage II: } 19 \\
\text { Stage III: } 57\end{array}$ \\
\hline T6B & 1 & 55 & 0.37 & $32 \%$ & Stage II: 20 g thermop. inoc. & $\begin{array}{l}\text { Stage I: } 24 \\
\text { Stage II: } 76\end{array}$ \\
\hline T7A, T7B & 1 & 55 & 0.39 & $\begin{array}{l}38 \% \text { (Stage I) } \\
75 \% \text { (Stage III) }\end{array}$ & Stage III: 70 g thermop. inoc. +530 g water ${ }^{(d)}$ & $\begin{array}{l}\text { Stage I: } 43 \\
\text { Stage III: } 57\end{array}$ \\
\hline T8A, T8B & 1 & 55 & 0.38 & $43 \%$ & Not used & Stage I: 103 \\
\hline
\end{tabular}

(a) Waste removed from reactor before inoculum and water addition. TS content Stage III: 2.66 kgTS

(b) Waste removed from reactor before inoculum and water addition. TS content Stage III: $0.21 \mathrm{kgTS}$ (T3A/B)- $0.24 \mathrm{kgTS}$ (T2A)

(c) Waste removed from reactor before inoculum addition. TS content Stage III: 0.36 kgTS

(d) Waste removed from reactor before inoculum and water addition. TS content Stage III: 0.22 kgTS (T7A/B) - 0.24 kgTS (T6A) 
Table 4 (Line 273)

\begin{tabular}{lcc}
\hline & Mean & Unit \\
\hline Initial water content, $W^{(*)}$ & $19.4 \pm 1.1$ & $(\% \mathrm{w} / \mathrm{w})$ \\
Water content at field capacity, $F C^{(*)}$ & $41 \pm 5$ & $(\% \mathrm{w} / \mathrm{w})$ \\
Total solids, TS ${ }^{(*)}$ & $80.6 \pm 1.0$ & $(\% \mathrm{w} / \mathrm{w})$ \\
Volatile solids, VS & $47.3 \pm 1.0$ & $(\% \mathrm{TS})$ \\
Organic carbon, TOC & $23.9 \pm 0.3$ & $(\% \mathrm{TS})$ \\
pH & 6.7 & -- \\
TKN & $14.1 \pm 2.0$ & $\mathrm{~g} / \mathrm{kgTS}$ \\
$\mathrm{NH}_{4}-\mathrm{N}$ & $2.0 \pm 0.2$ & $\mathrm{~g} / \mathrm{kgTS}$ \\
$\mathrm{COD}$ & $520 \pm 40$ & $\mathrm{~g} / \mathrm{kgTS}$ \\
Total VFA & $0.18 \pm 0.05$ & $\mathrm{~g} / \mathrm{l}$ \\
\hline
\end{tabular}

${ }^{(*)}$ expressed on wet weight basis 
Table 5 (Line 427)

\begin{tabular}{|c|c|c|c|c|c|c|c|}
\hline & \multirow{2}{*}{$\begin{array}{c}\mathrm{T}=20-25^{\circ} \mathrm{C} \\
\mathrm{R2}(\mathrm{W}=34 \%-75 \%)\end{array}$} & \multicolumn{3}{|c|}{$\mathrm{T}=37^{\circ} \mathrm{C}$} & \multicolumn{3}{|c|}{$\mathrm{T}=55^{\circ} \mathrm{C}$} \\
\hline & & T4B (W=43\%-50\%) & T2A (W=32\%-75\%) & T3 (W=39\%-75\%) & T8 (W=43\%) & T6A (W=32\%-75\%) & T7 (W=39\%-75\%) \\
\hline $\mathrm{L}_{0}$ (NI/kgTS) & 75 & 140 & 150 & 129 & 68 & 130 & 111 \\
\hline $\mathrm{t}_{\text {lag }}(\mathrm{d})$ & 103 & 75 & 73 & 69 & 39 & 59 & 52 \\
\hline$k\left(d^{-1}\right)$ & 0.007 & 0.028 & 0.044 & 0.054 & 0.038 & 0.110 & 0.110 \\
\hline$R^{2}$ & 0.993 & 0.991 & 0.972 & 0.996 & 0.992 & 0.981 & 0.986 \\
\hline$\% \mathrm{~L}_{0} / \mathrm{BMP}$ & 37.7 & 70.3 & 75.3 & 64.8 & 34.1 & 65.3 & 55.7 \\
\hline $\mathrm{T}_{99 \%}$ (d) & 658 & 165 & 104 & 85 & 121 & 42 & 42 \\
\hline
\end{tabular}


Table 6 (Line 447)

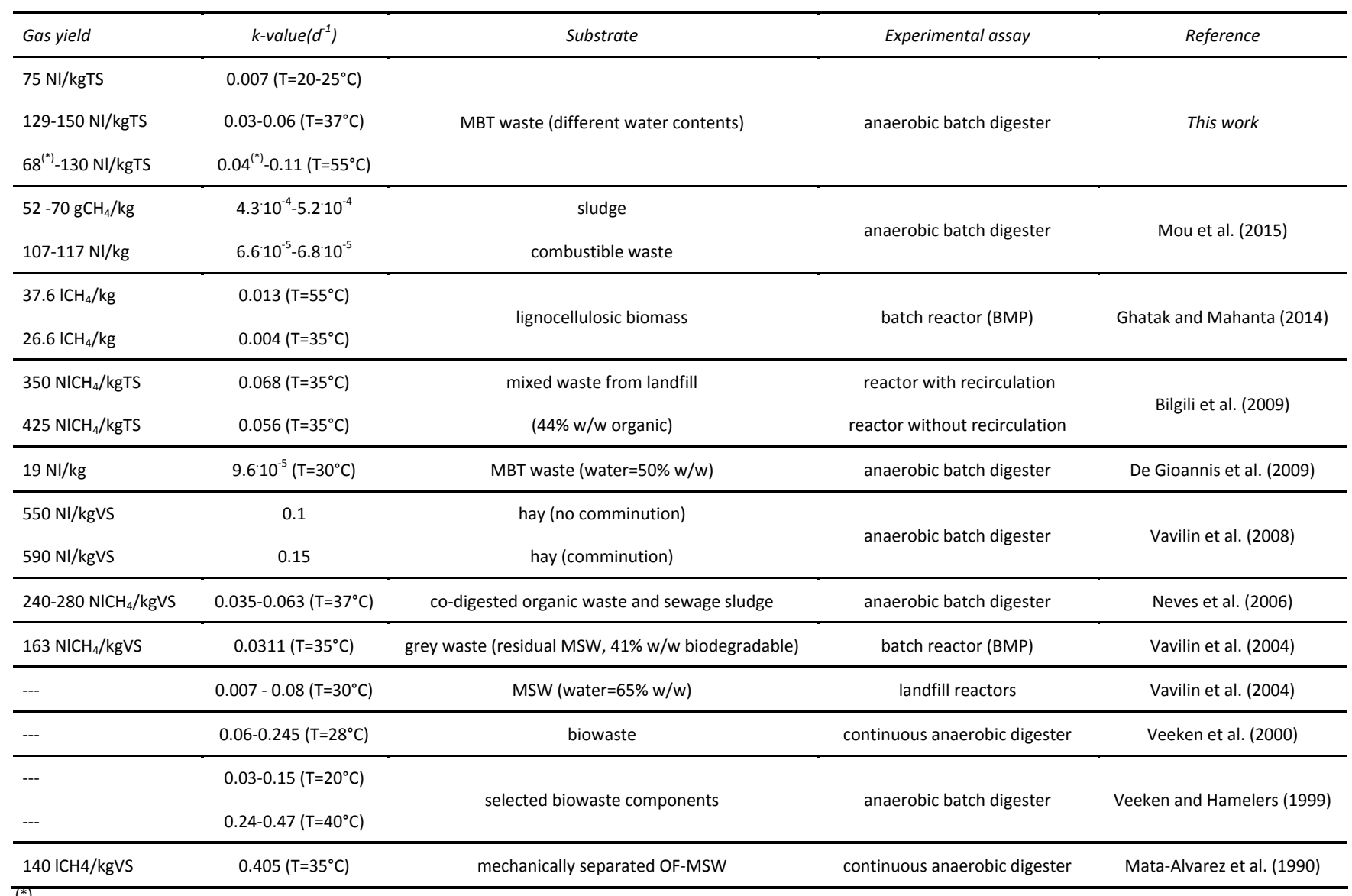

${ }^{(*)}$ values refer to 103 -days experiments performed at $55^{\circ} \mathrm{C}$ and $43 \%$ (wet weight) water content, without inoculum addition. 
Table 7 (Line 479)

\begin{tabular}{lcccc}
\hline SAMPLE & TKN $(\mathrm{g} / \mathrm{kgTS})$ & $\mathrm{NH}_{4}-\mathrm{N}(\mathrm{g} / \mathrm{kgTS})$ & $\mathrm{NH}_{4}-\mathrm{N} / \mathrm{TKN}(\%)$ & VFA $(\mathrm{g} / \mathrm{l})$ \\
\hline FRESH WASTE & $14.1 \pm 2.0$ & $2.0 \pm 0.2$ & 14.4 & $0.18 \pm 0.05$ \\
$\mathrm{R} 2\left(20-25^{\circ} \mathrm{C}, \mathrm{W}=34 \% \mathrm{w} / \mathrm{w}\right)$ & $15.2 \pm 1.2$ & $3.4 \pm 0.1$ & 22.7 & $5.42 \pm 0.24$ \\
$\mathrm{~T} 2 \mathrm{~A}\left(37^{\circ} \mathrm{C}, \mathrm{W}=32 \% \mathrm{w} / \mathrm{w}\right)$ & $15.2 \pm 0.6$ & $4.2 \pm 0.2$ & 27.4 & $6.28 \pm 0.58$ \\
$\mathrm{~T} 3\left(37^{\circ} \mathrm{C}, \mathrm{W}=38 \% \mathrm{w} / \mathrm{w}\right)$ & $14.1 \pm 0.9$ & $4.2 \pm 0.3$ & 30.1 & $7.57 \pm 0.31$ \\
$\mathrm{~T} 6 \mathrm{~A}\left(55^{\circ} \mathrm{C}, \mathrm{W}=32 \% \mathrm{w} / \mathrm{w}\right)$ & $14.1 \pm 1.4$ & $4.6 \pm 0.3$ & 32.4 & $7.94 \pm 0.93$ \\
$\mathrm{T7}\left(55^{\circ} \mathrm{C}, \mathrm{W}=38 \% \mathrm{w} / \mathrm{w}\right)$ & $15.0 \pm 1.3$ & $5.0 \pm 0.2$ & 33.6 & $7.56 \pm 0.83$ \\
\hline
\end{tabular}

2

3

4 


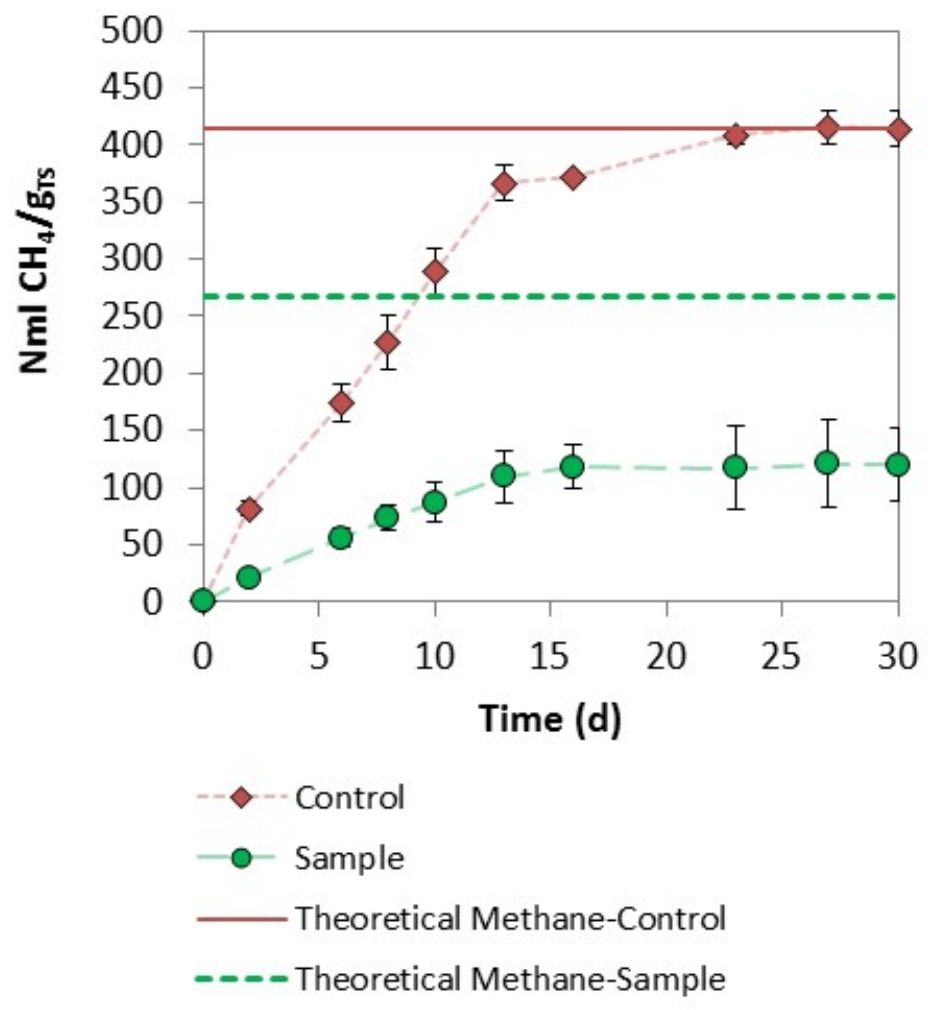


Figure 2 (Line 336)
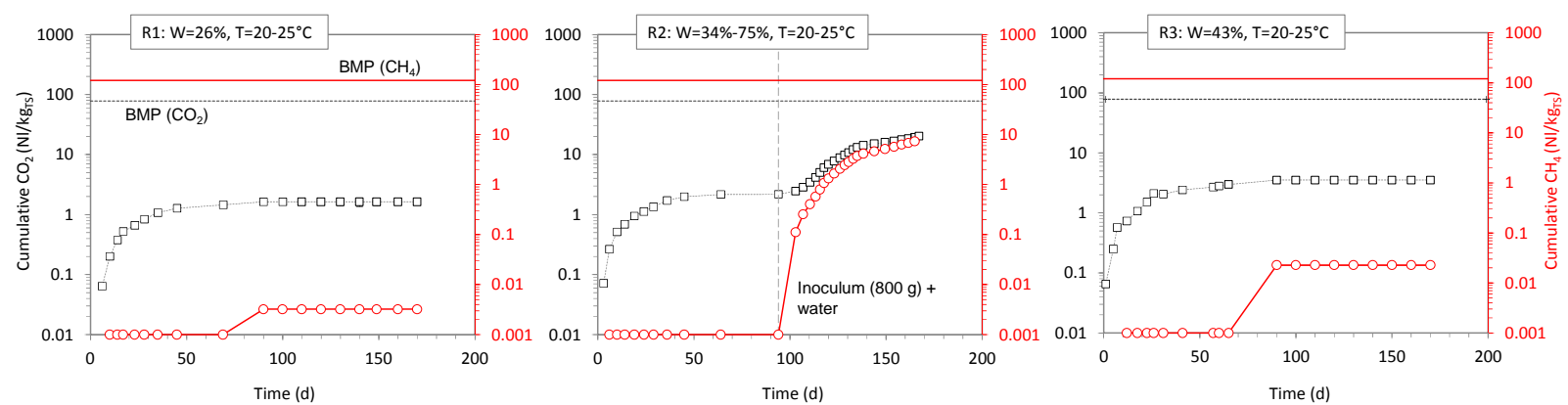

$\square \mathrm{CO}_{2} \quad \mathrm{BMP}\left(\mathrm{CO}_{2}\right) \quad-\mathrm{CH}_{4} \quad \mathrm{BMP}\left(\mathrm{CH}_{4}\right)$ 
Figure 3 (Line 338)
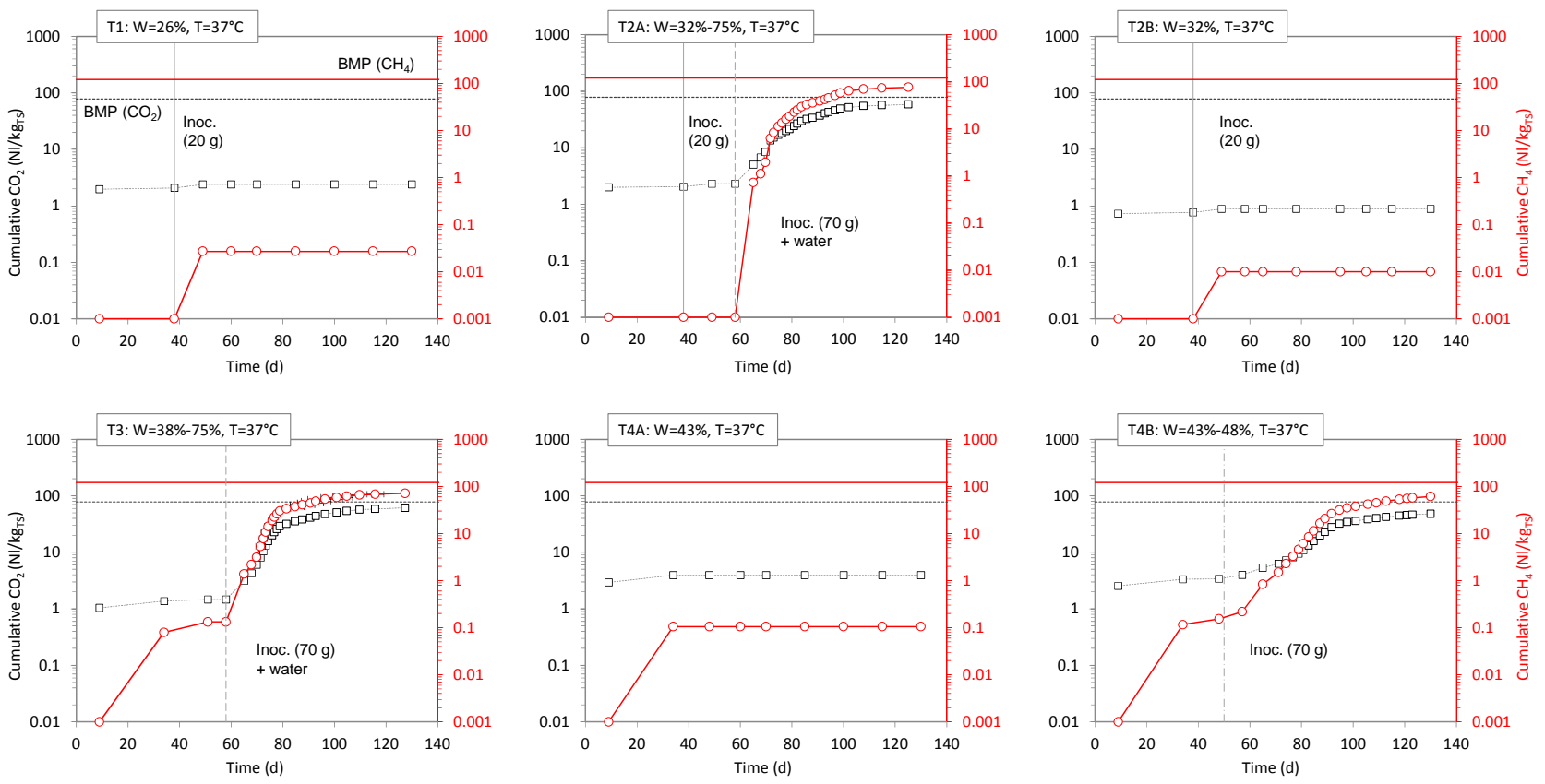

$\rightarrow \mathrm{CO}_{2} \quad-\mathrm{BMP}\left(\mathrm{CO}_{2}\right) \quad \mathrm{BMP}\left(\mathrm{CH}_{4}\right)$ 
Figure 4 (Line 340)
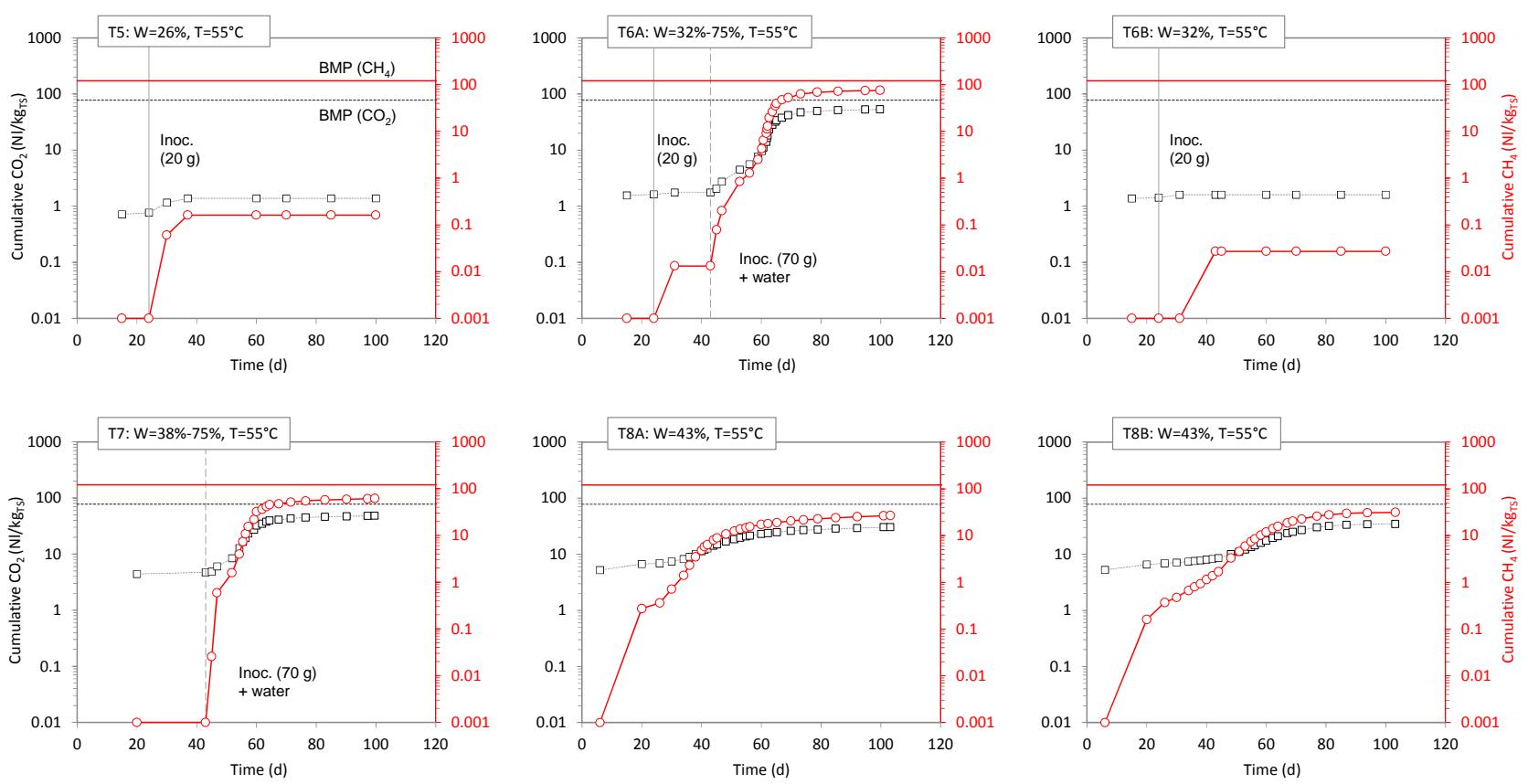

$\square \mathrm{CO}_{2} \quad-\mathrm{BMP}\left(\mathrm{CO}_{2}\right) \quad-\mathrm{CH}_{4} \quad \mathrm{BMP}\left(\mathrm{CH}_{4}\right)$ 
Figure 5 (Line 418)

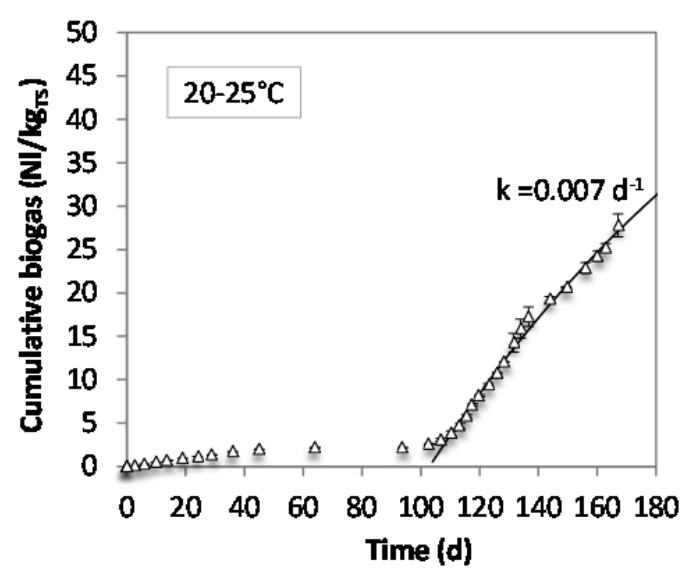

$\triangle W=34 \%-75 \%$ - Model
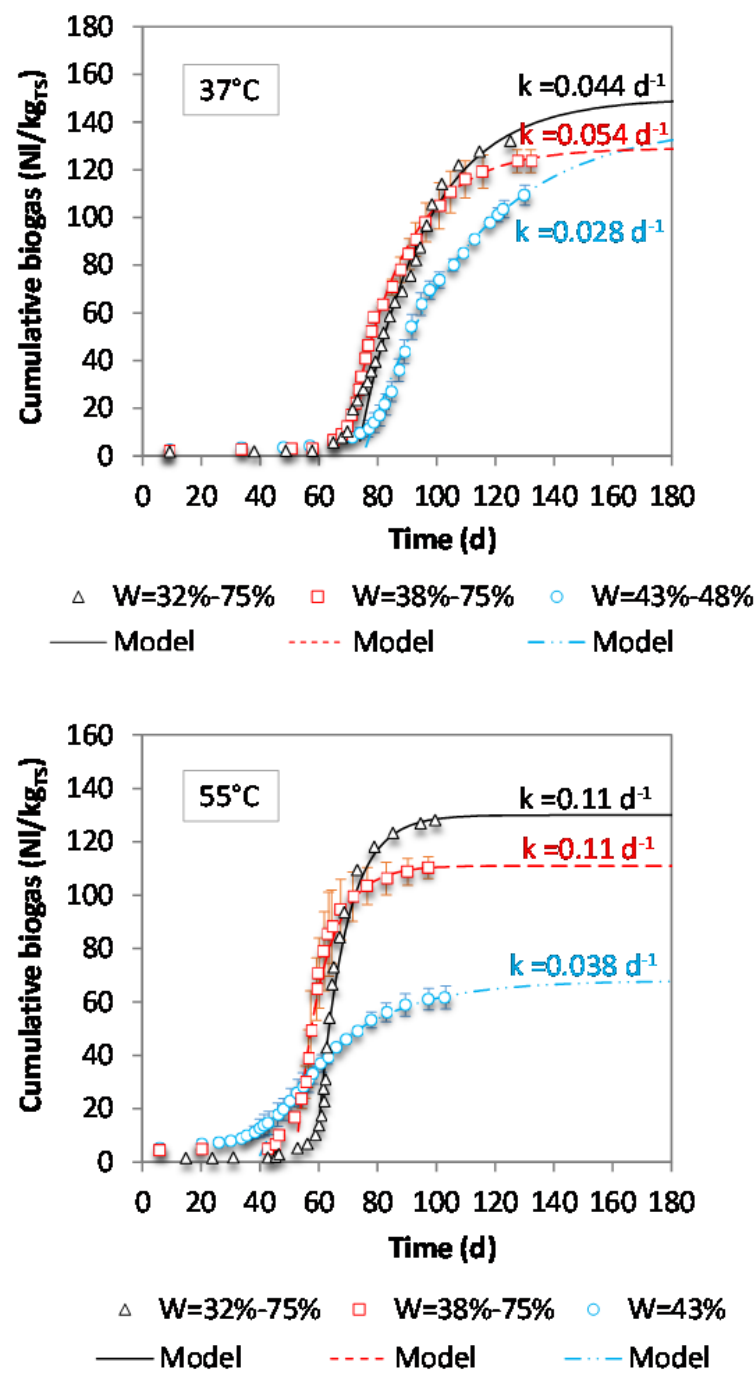
Supplementary Material for:

${ }^{1}$ Department of Civil Engineering and Computer Science Engineering, University of Rome "Tor Vergata"

Via del Politecnico, 1, 00133 Rome (Italy)

Tel.: +3906 72597497; fax: +390672597021

*E-mail address: pantini@ing.uniroma2.it

${ }^{2}$ Department of Environmental Engineering, Technical University of Denmark Miljoevej, Building 113, DK-2800 Kgs. Lyngby (Denmark)

Tel.: +45 45251561; fax: +4545932850

\section{Table of contents}

Figure S1. Gas composition (percentage by volume) measured in tests at room temperature $\left(20-25^{\circ} \mathrm{C}\right.$ ) and initial water content of $32 \%-75 \%$ (R2) and $43 \%$ (R3). Solid grey line: starting point of stage III. 50 Figure S2. Gas composition (percentage by volume) measured in tests at $37^{\circ} \mathrm{C}$ and initial water content of 32\%-75\% (T2A), 32\% (T2B), 38\%-75\% (T3A/B), 43\% (T4A) and 43\%-48\% (T4B). Dotted grey line: starting point of stage II. Solid grey line: starting point of stage III.

Figure S3. Gas composition (percentage by volume) measured in tests at $55^{\circ} \mathrm{C}$ and initial water content of 32\%-75\% (T6A), 32\% (T6B), 38\%-75\% (T7A/B), 43\% (T8A/B). Dotted grey line: starting point of stage II. Solid grey line: starting point of stage III. 
7 Figure S1. Gas composition (percentage by volume) measured in tests at room temperature $\left(20-25^{\circ} \mathrm{C}\right)$ and initial water content of 32\%-75\% (R2) and $43 \%$ (R3). Solid grey line: starting point of stage III.

$R 2$ : $W=34 \%-75 \%, T=20-25^{\circ} \mathrm{C}$



$R 3: W=43 \%, T=20-25^{\circ} \mathrm{C}$

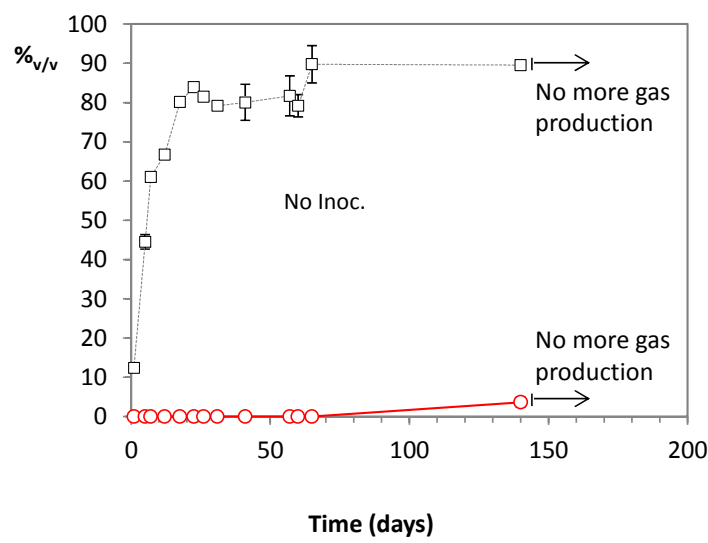


18 Figure S2. Gas composition (percentage by volume) measured in tests at $37^{\circ} \mathrm{C}$ and initial water content of $32 \%-75 \%$ (T2A), 32\% (T2B), 38\%-75\% (T3A/B), 43\% (T4A) and 43\%-48\% (T4B). Dotted grey line: starting point of stage II. Solid grey line: starting point of stage III.
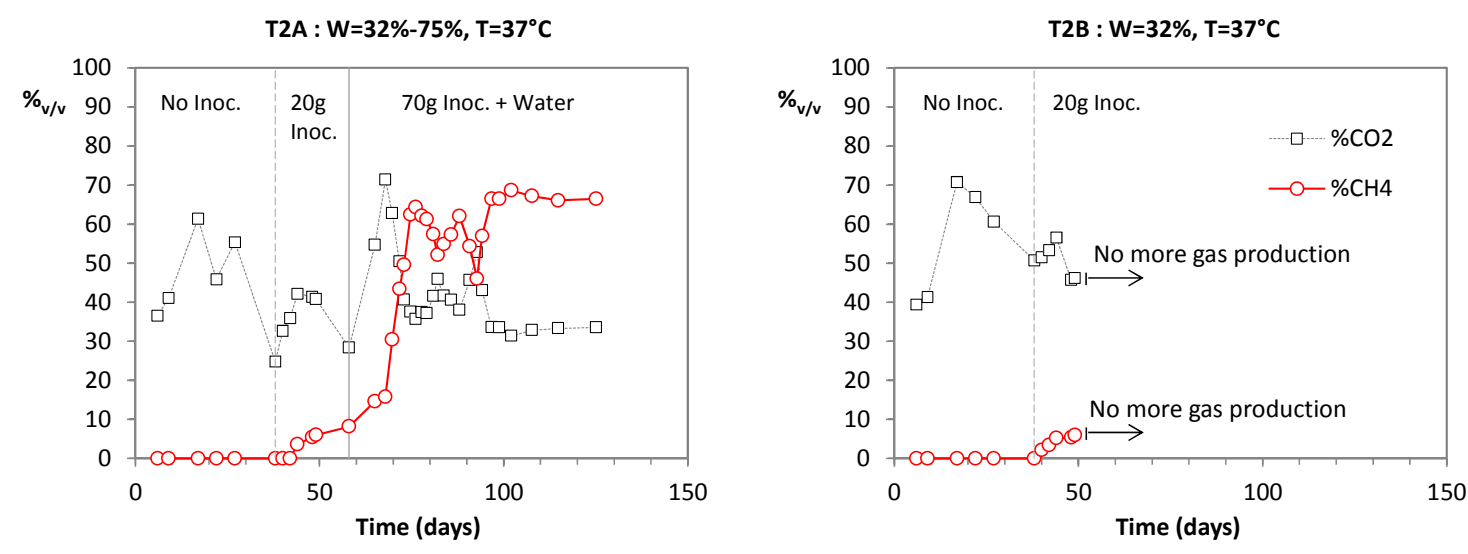

T3A : $\mathbf{W}=38 \%-75 \%, \mathrm{~T}=37^{\circ} \mathrm{C}$
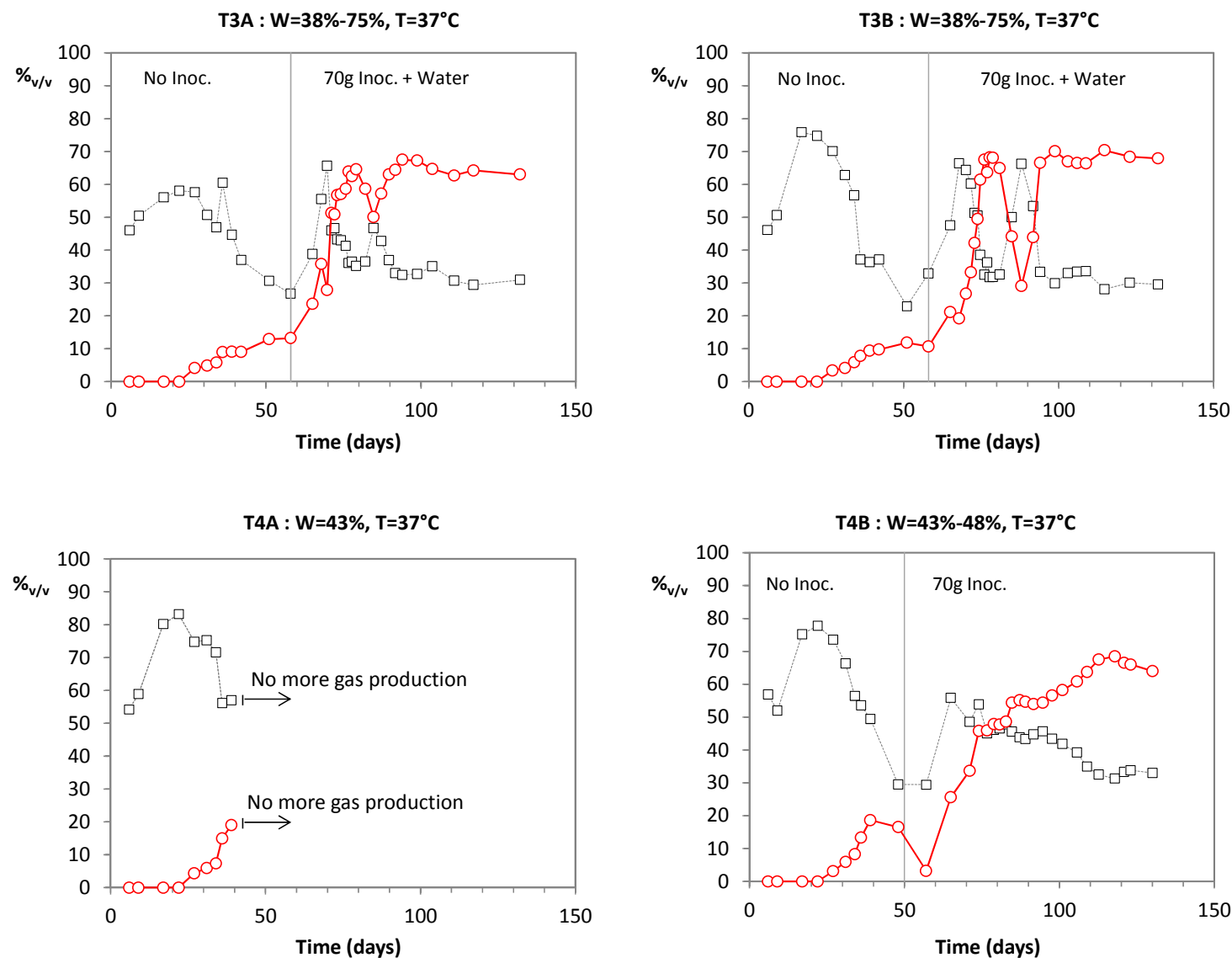
89 Figure S3. Gas composition (percentage by volume) measured in tests at $55^{\circ} \mathrm{C}$ and initial water content of 32\%-75\% (T6A), 32\% (T6B), 38\%-75\% (T7A/B), 43\% (T8A/B). Dotted grey line: starting point of stage II. Solid grey line: starting point of stage III.

T6A : W=32\%-75\%, $\mathrm{T}=55^{\circ} \mathrm{C}$

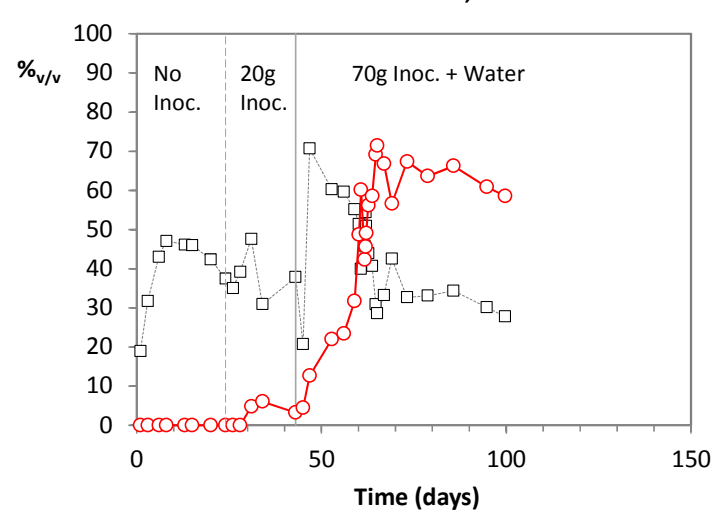

T7A : $W=38 \%-75 \%, T=55^{\circ} \mathrm{C}$

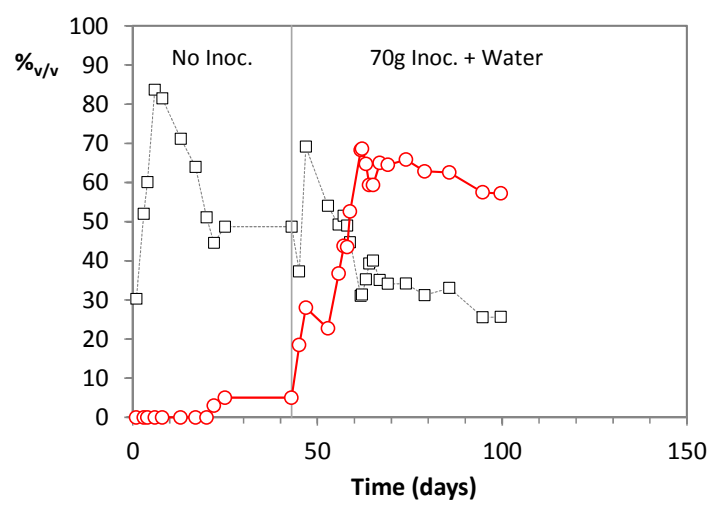

$\mathrm{T} 8 \mathrm{~A}: \mathrm{W}=43 \%, \mathrm{~T}=55^{\circ} \mathrm{C}$

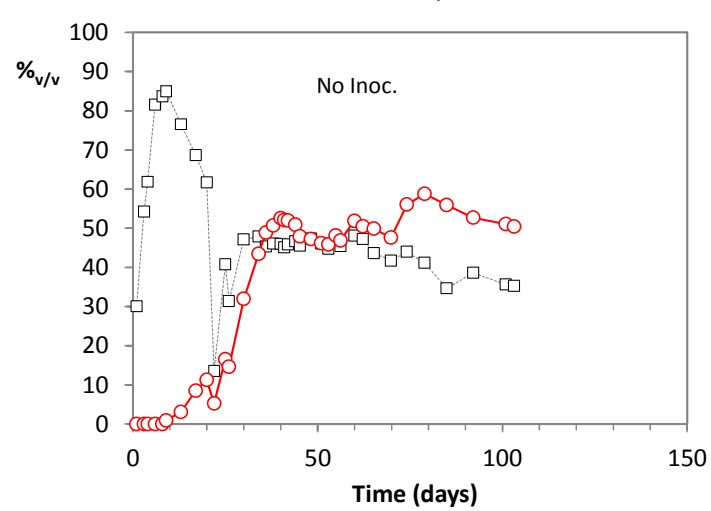

T6B : $W=32 \%, T=55^{\circ} \mathrm{C}$

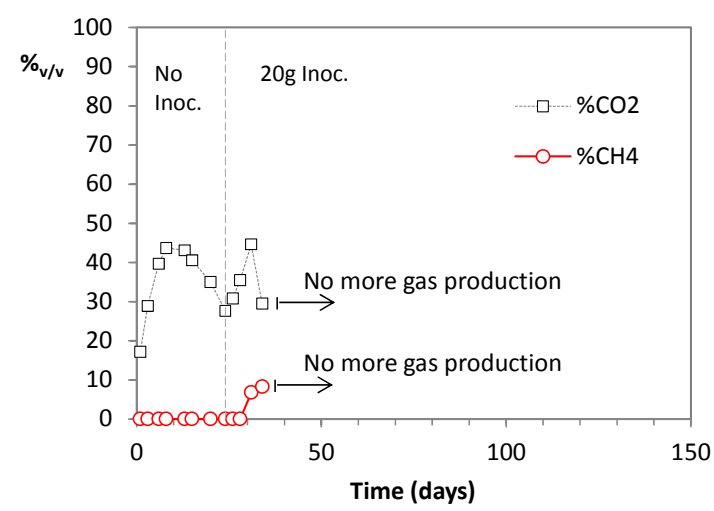

T7B : $W=38 \%-75 \%, T=55^{\circ} \mathrm{C}$

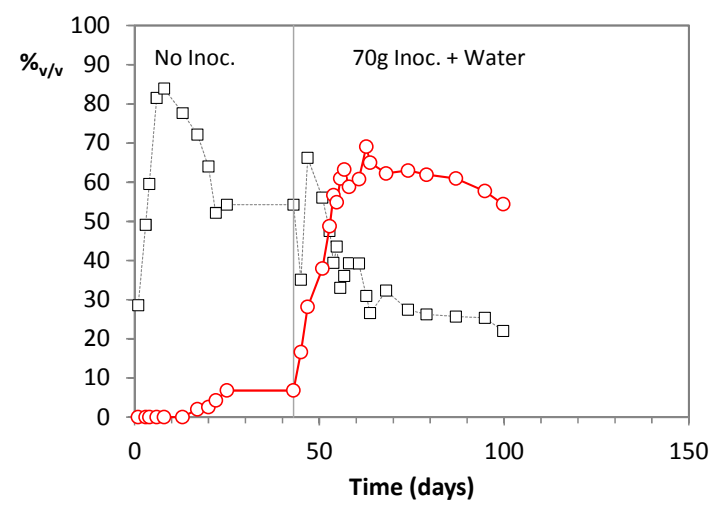

$\mathrm{T} 8 \mathrm{~B}: \mathrm{W}=43 \%, \mathrm{~T}=55^{\circ} \mathrm{C}$

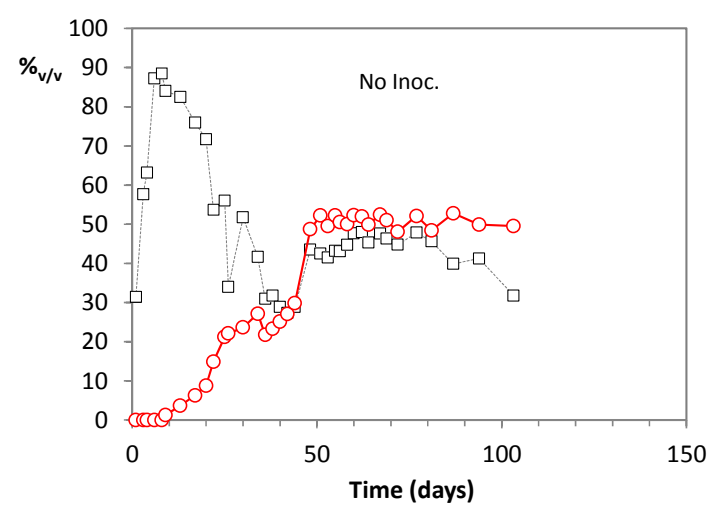

